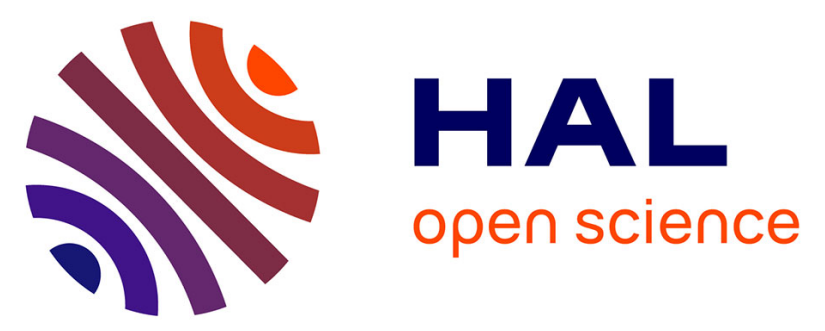

\title{
Development of a secondary organic aerosol formation mechanism: comparison with smog chamber experiments and atmospheric measurements
}

L. E. Olcese, J. E. Penner, S. Sillman

\section{- To cite this version:}

L. E. Olcese, J. E. Penner, S. Sillman. Development of a secondary organic aerosol formation mechanism: comparison with smog chamber experiments and atmospheric measurements. Atmospheric Chemistry and Physics Discussions, 2007, 7 (3), pp.8361-8393. hal-00302874

\section{HAL Id: hal-00302874 \\ https://hal.science/hal-00302874}

Submitted on 18 Jun 2007

HAL is a multi-disciplinary open access archive for the deposit and dissemination of scientific research documents, whether they are published or not. The documents may come from teaching and research institutions in France or abroad, or from public or private research centers.
L'archive ouverte pluridisciplinaire HAL, est destinée au dépôt et à la diffusion de documents scientifiques de niveau recherche, publiés ou non, émanant des établissements d'enseignement et de recherche français ou étrangers, des laboratoires publics ou privés. 
Development of a SOA formation mechanism

\section{Development of a secondary organic aerosol formation mechanism: comparison with smog chamber experiments and atmospheric measurements}

L. E. Olcese et al.

\section{E. Olcese, J. E. Penner, and S. Sillman}

Department of Atmospheric, Oceanic and Space Sciences, University of Michigan, Ann Arbor, MI 48109, USA

Received: 20 April 2007 - Accepted: 30 May 2007 - Published: 18 June 2007

Correspondence to: L. E. Olcese (lolcese@umich.edu)

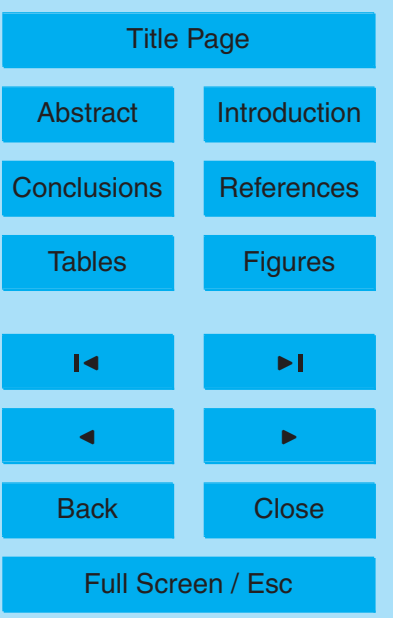

Printer-friendly Version 


\section{Abstract}

A new mechanism to simulate the formation of secondary organic aerosols (SOA) from reactive primary hydrocarbons is presented, together with comparisons with experimental smog chamber results and ambient measurements found in the literature. The

5 SOA formation mechanism is based on an approach using calculated vapor pressures and a selection of species that can partition to the aerosol phase from a gas phase photochemical mechanism. The mechanism has been validated against smog chamber measurements using $\alpha$-pinene, xylene and toluene as SOA precursors, and has an average error of $17 \%$. Qualitative comparisons with smog chamber measurements using isoprene were also performed. A comparison against SOA production in the TORCH 2003 experiment (atmospheric measurements) had an average error of only $12 \%$. This contrasts with previous efforts, in which it was necessary to increase partition coefficients by a factor of 500 in order to match the observed values. Calculations for rural and urban-influenced regions in the eastern U.S. suggest that most of 15 the SOA is biogenic in origin, mainly originated from isoprene. A 0-dimensional calculation based on the New England Air Quality Study also showed good agreement with measured SOA, with about $40 \%$ of the total SOA from anthropogenic precursors. This mechanism can be implemented in a general circulation model (GCM) to estimate global SOA formation under ambient NOx and HOx levels.

\section{Introduction}

Particulate matter (PM) plays a highly important role in the atmosphere. It exerts a strong influence on climate, modifying the amount of incoming radiation and changing the properties of clouds, in addition to other indirect effects. Organic matter (OM) can contribute up to $90 \%$ of the total mass of PM (Tsigaridis and Kanakidou, 2003), and a significant fraction of the OM is secondary organic aerosols (SOA), as high as $80 \%$ in polluted regions (Turpin and Huntzicker, 1995). SOA are not emitted directly

\section{Development of a SOA formation mechanism}

L. E. Olcese et al.

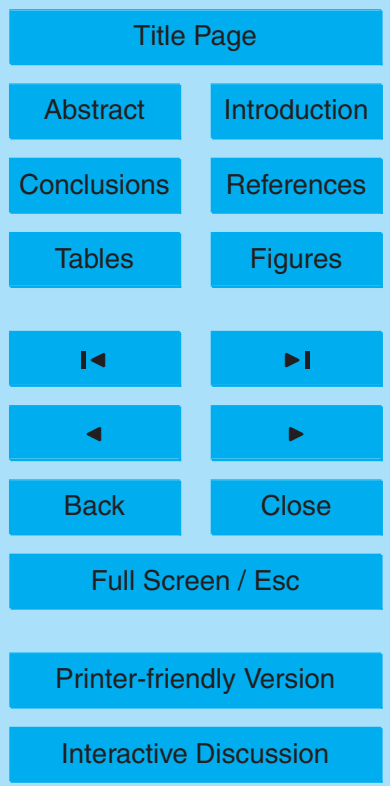


to the atmosphere, but are formed from semi-volatile oxygenated compounds, that are produced from the reaction of primary volatile hydrocarbons with oxidants such as $\mathrm{O}_{3}, \mathrm{OH}$ and $\mathrm{NO}_{3}$. These semi-volatile compounds have a wide variety of chemical and thermodynamic properties and usually have one or more functional groups, (i.e. 5 hydroxyl, carbonyl, carboxy, nitroxy and nitro groups). They may stick to the surface of primary carbonceous particles (POA) particles, which are mainly composed of black carbon (BC) and other nonvolatile organic compounds (OC).

The SOA precursors can be of biogenic and anthropogenic origin; the proper determination of the relative importance of both kinds of precursors is critical to the further 10 implementation of SOA abatement policies and to the identification of climate effects associated with anthropogenic OM.

Formation of SOA is poorly represented in current global chemical models, and this may be one of the main reasons why GCM models cannot properly reproduce aerosol field measurements. Previous efforts to model SOA formation in global mod-

15 els used different SOA formation methods and chemical mechanisms (e.g. Tsigaridis and Kanakidou, 2003 and Chung and Seinfeld, 2002), but when updated emission inventories for primary particle emissions are used, SOA formation is unable to explain observations of OC (Heald et al., 2005). One of the main problems with the SOA concentration simulations is that there are many uncertainties in the SOA formation mechanism, including the sticking coefficients of the semi-volatile compounds on aerosols, the enthalpy of vaporization of several compounds, stabilization of the compounds in the aerosol phase due to catalysis, formation of dimers and oligomers in the aerosol phase, and removal processes. Different methods have been proposed to simulate SOA formation, mainly based on coefficients derived from smog chamber measurements, but often these experiments use SOA precursors in higher concentration than their usual values in the atmosphere (e.g. Hoffmann et al., 1997). These methods often can reproduce SOA concentrations obtained from measurements in smog chamber experiments or in atmospheric measurements (e.g. Griffin et al., 2002), but, as explained below, the empirical coefficients so derived cannot provide information about

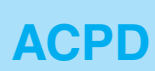

7, 8361-8393, 2007

\section{Development of a SOA formation mechanism}

L. E. Olcese et al.

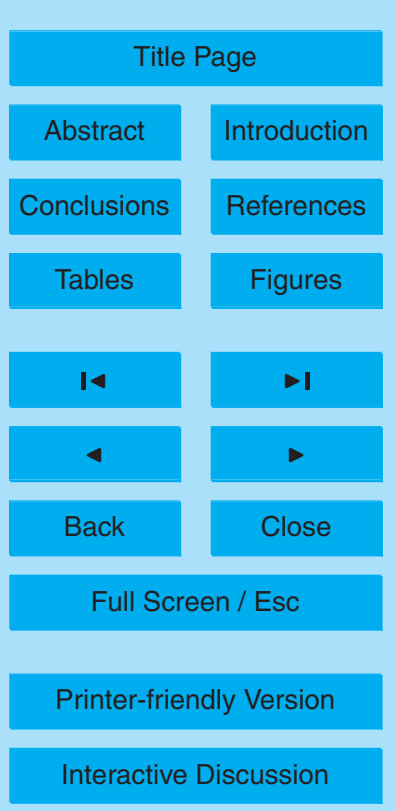

EGU 
the chemical species that form the SOA, and thus make it difficult to understand any further processes that occur in the aerosol phase.

The method used, with minor variations, by several authors (e.g. Chung and Seinfeld, 2002), is a two-product modeling framework for SOA formation. A parent hydrocarbon $5 \mathrm{HC}_{i}$ reacts in the gas phase with an oxidant $\mathrm{OX}_{j}\left(\mathrm{OH}, \mathrm{O}_{3}\right.$ or $\left.\mathrm{NO}_{3}\right)$ to form a set of products $\mathrm{G}_{i, j, k}$, each with a mass based stoichiometric coefficient $\alpha_{i, j, k}$ :

$\mathrm{HC}_{i}+\mathrm{OX}_{j} \stackrel{k_{i, j}}{\longrightarrow} \alpha_{i, j, 1} \mathrm{G}_{i, j, 1}+\alpha_{i, j, 2} \mathrm{G}_{i, j, 2}$

Where $k_{i, j}$ is the reaction rate coefficient. Typically, $k_{i, j}$ and the stoichiometric coefficients $\alpha_{i, j, k}$ are determined by fits to smog chamber experiments, and the chemical structure of the products $\mathrm{G}_{i, j, k}$ remains unknown. This is one of the main drawbacks to this kind of SOA formation mechanism, but has been necessitated by the fact that the experimental data for the product constituents are not always available. In addition, this procedure limits the inclusion of new compounds in the SOA formation mechanism, since reactions inside the aerosol phase cannot be included.

Here, we describe a mechanism for SOA formation based on an explicit representation of chemical reactions of gas-phase species. Vapor pressures of the secondary compounds formed from the oxidation of primary species and its partitioning constants from gas to aerosol phase are calculated from thermodynamic considerations. Similar methods have been used previously by Griffin et al. (2002), Zhang et al. (2004) and 20 Pun et al. (2006). Our methods, based on a different chemical mechanism, differ in the method used to estimate the partition coefficients, in the SOA precursor selection, and in the treatment of hydrophilic and hydrophobic aerosols.

The resulting mechanism has been evaluated in comparison with smog chamber experiments. The mechanism is also used in 0-dimensional calculations that represent 25 conditions associated with two recent field campaigns: the TORCH 2003 experiment (Utembe et al., 2005; Johnson et al., 2006a and Johnson et al., 2006b) and the 2002 New England Air Quality Study, (De Gouw et al., 2005). Previous attempts to explain these measurements through calculations have been unsatisfactory. As described be-

\section{Development of a SOA formation mechanism}

L. E. Olcese et al.

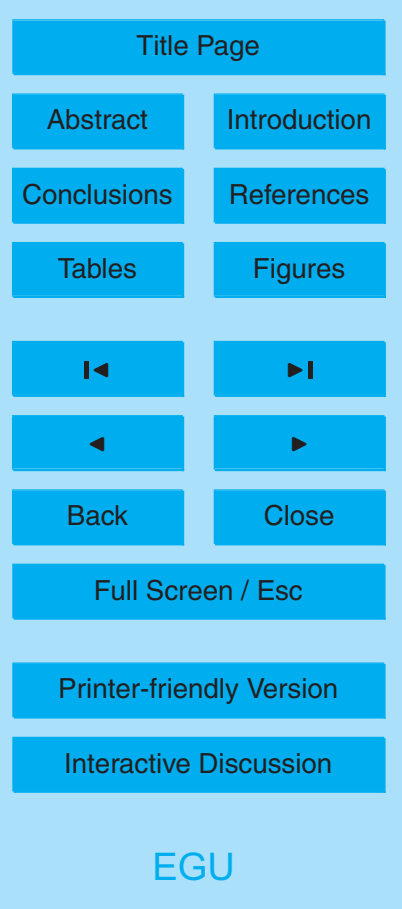


low, calculations using the mechanism described here show improved agreement in comparison with measurements.

The ultimate goal of this work is to develop a method for use in a global 3-D chemical and transport model (IMPACT) to simulate global SOA production, including up5 dated emission inventories and a large number of primary compounds that can produce aerosols together with a detailed model of the chemical reactions inside the particles.

\section{Model description}

SOA are produced through the partitioning of selected organic carbon compounds between the gas and a preexisting aerosol phase, composed of an absorptive medium

10 like primary organic aerosols and black carbon. The newly formed SOA can also serve as an absorptive medium for other low volatility organic compounds.

The widely accepted (Pankow, 1994a) representation of the partitioning process of a given species between the gas phase and the aerosol phase depends on several chemical and physical variables, including the vapor pressure of the species, the av15 erage molecular weight of the compounds in the aerosol phase, the temperature, as well as the concentrations of the species in both phases and the chemical composition of the aerosol phase. The numerical value of most of these variables can be measured, usually with small errors, or can be estimated using different methods for approximation. In this work, a detailed gas-phase chemical mechanism is used to sim20 ulate the production of semi-volatile oxygenated compounds and their condensation to the aerosol-phase to produce SOA. Thus, we aim to establish a mechanistic representation of the physical and chemical processes of SOA formation.

The chemical mechanism used is based on that published by lto et al. (2007). It includes 194 chemical species and 611 chemical reactions and includes a change 25 that forms glycoaldehyde from the oxidation of isoprene rather than hydroxyacetic acid. A distinctive characteristic of the solution method is that it is based on an analysis of odd hydrogen production and loss, leading to a fast calculation of the

\section{Development of a SOA formation mechanism}

L. E. Olcese et al.

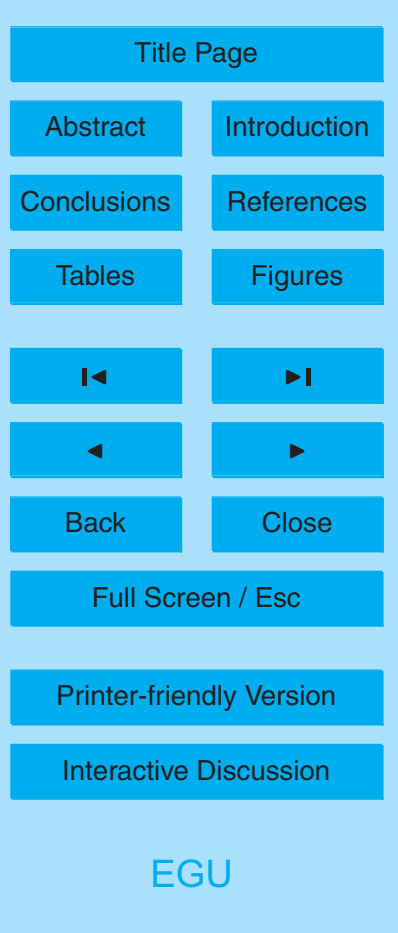


species concentration in each time step (Sillman, 1991). We also ran some of the tests described in the following sections using the Master Chemical Mechanism (MCM) v3.1 (http://mcm.leeds.ac.uk/MCM/, 2006), and we found that, by choosing the same species for partitioning (or an equivalent one, if the species is not present in both mech5 anisms), the amount of SOA formed in the simulations using the lto et al. mechanism and the MCM mechanism, was almost the same. This is a good indication of the robustness of the chosen chemical mechanism, whose computational requirements are much smaller than those of the MCM.

In our proposed approach, every secondary organic compound that meets at least

one of the following requirements, established by Griffin et al. (2002), has the potential to partition to the aerosol phase. A compound must have at least one of the following structural characteristics:

- Be partially soluble.

- Be an aromatic acid.

- Be an aromatic compound with two functional groups that are not aldehydes.

- Have 12 or more carbon atoms.

- Have at least 10 carbon atoms and two functional groups.

- Have at least six carbon atoms and two functional groups, one of which is an acid.

- Be trifunctional.

20 From these criteria, 23 species, taken from the Ito et al. chemical mechanism, with the potential to produce SOA were selected (Table 1). All the species were oxygenated derivatives from aromatics, isoprene, $\alpha$-pinene, limonene and carbonyls.

The formation of SOA from the products of isoprene oxidation is not clear, as some studies show that isoprene produces only minor amounts of SOA, and then only under acidic conditions (Kroll et al., 2005, Pandis et al., 1991, Edney et al., 2005), but other

\section{Development of a SOA formation mechanism}

L. E. Olcese et al.

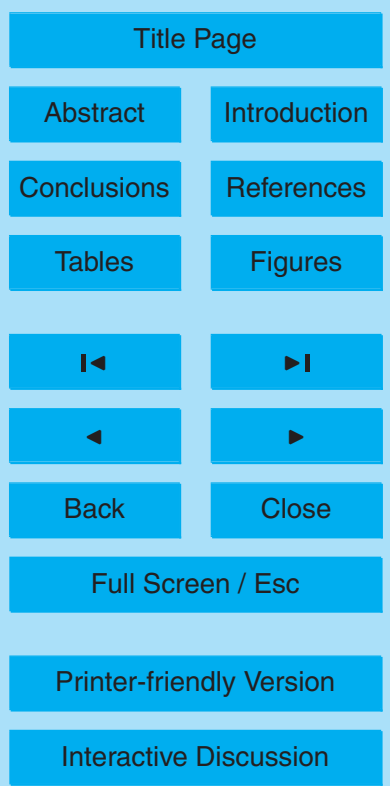

EGU 
studies estimate higher levels of SOA formed from the secondary oxygenated products of isoprene (Henze and Seinfeld, 2006; Matsunaga et al., 2005; van Donkelaar, 2007; Surrat et al., 2006). Henze and Seinfeld (2006) reported that the SOA formed from isoprene can be very important in the free troposphere and in remote marine regions.

5 Smog chamber experiments using isoprene as an SOA precursor are very scarce, and have mostly been performed under acidic conditions. We included isoprene derived species as SOA because they meet the required structural characteristics and because the ambient simulations shown below that used these compounds gave results closer to the experimental values.

10 Smog chamber experiments have also shown that the semi-volatile photooxidation products of organic compounds tend to polymerize in the aerosol phase in reactions catalyzed by the semi-volatile acidic reaction products (Kalberer et al., 2004). Another smog-chamber study on the effect of acidic seed particles on $\alpha$-pinene ozonolysis suggested that acidity promotes SOA formation and increases aerosol yield by up to $40 \%$ (linuma et al., 2004). The acid catalysis and the polymerization reactions have not yet been incorporated into our model, but their inclusion is feasible.

Preliminary simulations under different atmospheric conditions and with different mixes of precursors showed that only 7 of the 23 secondary semi-volatile oxygenated species that have been selected as capable of partitioning to the aerosol phase do, in fact, partition in significant quantities under typical rural and urban atmospheric conditions and patterns of emissions. In the following, since the computational requirements to process the SOA partitioning are very low, all species have been included, but similar results are obtained when including only these species for the particular emission or meteorological conditions, assumed here. Table 1 also shows the partitioning coefficient $K_{i}$ and the species that partition in significant quantities. The species of most importance for partitioning to the aerosol phase are: 
A-DI Product of decomposition of carbonyl $\left[\mathrm{C}_{6} \mathrm{H}_{5} \mathrm{OH}(\mathrm{OH}) \mathrm{CHO}\right]$

$\mathrm{ACHO}$ Benzaldehyde $\left[\mathrm{C}_{6} \mathrm{H}_{5} \mathrm{CHO}\right]$

IALD Hydroxy carbonyl alkene from isoprene $\left[\mathrm{HOCH}_{2} \mathrm{C}\left(\mathrm{CH}_{3}\right)=\mathrm{CHCHO}\right]$

INPN Peroxide from isoprene $\left[\mathrm{ONO}_{2} \mathrm{CH}_{2} \mathrm{C}(\mathrm{OOH})\left(\mathrm{CH}_{3}\right) \mathrm{CH}=\mathrm{CH}_{2}\right]$

ISNP Peroxide from isoprene $\left[\mathrm{HOCH}_{2} \mathrm{C}(\mathrm{OOH})\left(\mathrm{CH}_{3}\right) \mathrm{CH}\left(\mathrm{ONO}_{2}\right) \mathrm{CH}_{2} \mathrm{OH}\right]$

NITP Benzyl nitrate $\left[\mathrm{C}_{6} \mathrm{H}_{5} \mathrm{ONO}_{2}\right]$

PINT Acid from terpenes [ $\mathrm{ONO}_{2} \mathrm{C}_{10} \mathrm{H}_{16} \mathrm{OOH}$ ]

The concentration of each specie $A_{i}$ in the aerosol phase is given by (Pankow, 1994a and Pankow, 1994b):

$5\left[A_{i}\right]_{\mathrm{gas}}=\frac{\left[A_{i}\right]_{\text {aerosol }}}{K_{i} M_{0}}$

$M_{0}=[\mathrm{POA}]+\sum_{i=1, n}\left[A_{i}\right]_{\text {aerosol }}$

Where $n$ is the number of species that can partition to the aerosol phase, $\left[A_{i}\right]_{\text {aerosol }}$ $\left(\mu \mathrm{g} \mathrm{m}^{-3}\right)$ and $\left[A_{i}\right]_{\text {gas }}\left(\mu \mathrm{g} \mathrm{m}^{-3}\right)$ are the concentrations of the specie $A_{i}$ in the aerosol and gas phase, respectively, and $K_{i}\left(\mathrm{~m}^{3} \mu \mathrm{g}^{-1}\right)$ is its partitioning coefficient between the aerosol and gas phases. $M_{0}\left(\mu \mathrm{g} \mathrm{m}^{-3}\right)$ is the concentration of total organic aerosols and [POA] $\left(\mu \mathrm{g} \mathrm{m}^{-3}\right)$ is the concentration of primary organic aerosols. Both equations are solved iteratively (Typically, about five iterations in each time step).

The partitioning coefficient $K_{i}$ for each compound is calculated according to:

$K_{i}=\frac{R T}{10^{6} M W \zeta_{i} p_{L, i}^{O}}$

15 Where $R\left(8.206 \times 10^{-5}\right.$ atm $\left.\mathrm{m}^{3} \mathrm{~mol}^{-1} \mathrm{~K}^{-1}\right)$ is the ideal gas constant, $T(\mathrm{~K})$ is the temperature, $M W\left(\mathrm{~g} \mathrm{~mol}^{-1}\right)$ is the average molecular weight of the absorbing aerosol phase, $\zeta_{i}$ (dimensionless) is the activity coefficient of the compound in the organic aerosol

Development of a SOA formation mechanism

L. E. Olcese et al.

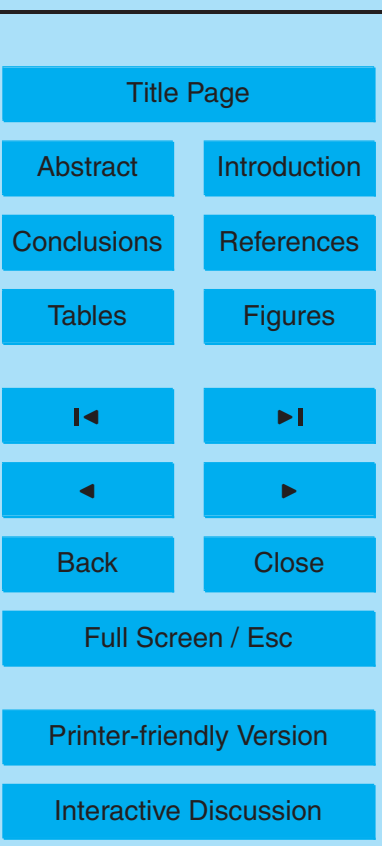


phase, $p_{L, i}^{O}(\mathrm{~atm})$ is the compound vapor pressure (sub-cooled if necessary) and $10^{6}$ is a unit conversion factor $\left(\mathrm{g}_{\mu \mathrm{g}}{ }^{-1}\right)$.

As vapor pressure experimental data for several secondary species is not available, the Myrdal and Yalkowsky (1997) estimation method has been used, with some 5 changes added to include the particular chemical structure of the SOA forming compounds (Camredon and Aumont, 2006). The Myrdal and Yalkowsky method estimates the boiling point of a given organic compound based on the Joback group contribution method (Reid et al., 1987), and then estimates the vapor pressure at a given temperature.

10 Several authors (e.g. Pankow, 1994a and Kamens et al., 1999) have stated that it is reasonable to assume that the value of $\zeta_{i}$ is equal to one for a given oxidation product in an aerosol droplet composed of a mixture of similar species. Although some methods (Bowman and Karamalegos, 2002) which are also based on group contributions have been proposed to estimate the activity coefficient, we set $\zeta_{i}$ equal to one for simplicity.

15 Activity coefficients $\zeta_{i}$ are temperature dependant, but their variation with temperature is negligible compared to the temperature dependence of the vapor pressure.

The partition process between the gas phase and the aerosol phase is assumed to be instantaneous, due to the relevant relative reaction and transport time scales, as calculated by Bowman et al. (1997) in a reactor chamber system. Thus, the amount of each secondary compound that partitions to the aerosol phase does not depend on the timestep used, but only on the Eq. (1). The partition equations are solved after the gas phase concentrations are obtained for each step. The updated gas phase concentrations of the secondary compounds are used in the next step.

As the smog chamber experiments last for only a few hours, no wet or dry removal 25 mechanism has been included in the model, although the wall removal processes are set to the published values for each smog chamber. The wall removal process is simulated by either assuming a rate constant for the wall loss reactions, or by removing a fixed percentage of the mass of some selected species during each time step, depending on each smog chamber.

\section{Development of a SOA formation mechanism}

L. E. Olcese et al.

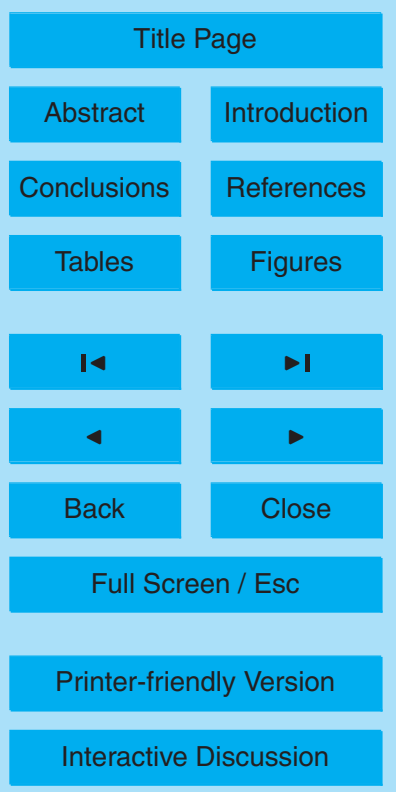

EGU 
The main sink process for organic aerosols in the ambient atmosphere is wet deposition, which represents 70 to $85 \%$ of the total deposition process (Kanakidou et al., 2005), so only this process has been considered in our ambient simulations. Deposition is included by assuming a lifetime of seven days, based on the Kanakidou 5 et al. (2005) work and AEROCOM intercomparison results (http://nansen.ipsl.jussieu. $\mathrm{fr} / \mathrm{AEROCOM} /, 2006)$. Small variations in the lifetime have little effect on the results shown in Sect. 3.2.

\section{Simulations and results}

To validate the model, two different approaches have been used: One, presented in 10 Sect. 3.1, involves the comparison of the model results with smog chamber experiments found in the literature. The second, in Sect. 3.2, involves the comparison of 0 -dimensional calculations using with ambient measurements of $O A$ taken during the TORCH 2003 campaign under several conditions. In Sect. 3.3 we also present generalized simulations under urban-influenced and rural atmospheric conditions using 15 representative emission values. In addition, a simulation of a New England plume and comparison with ambient measurements is presented.

\subsection{Comparison with smog chamber results}

Experimental measurements of SOA formation in smog chambers under controlled conditions and using different precursors are difficult, and therefore only a few results are available in literature. Two different sets of SOA formation smog chamber experiments have been selected to test this model; one set of experiments (18 different initial conditions) reported by Takekawa et al. (2003), used toluene, $\mathrm{m}$-xylene and $\alpha$ pinene as SOA precursors under different $\mathrm{NO}$ and $\mathrm{NO}_{2}$ initial concentrations, at two different temperatures. They also injected propene to accelerate the photochemical

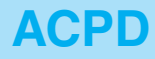

7, 8361-8393, 2007

\section{Development of a SOA formation mechanism}

L. E. Olcese et al.

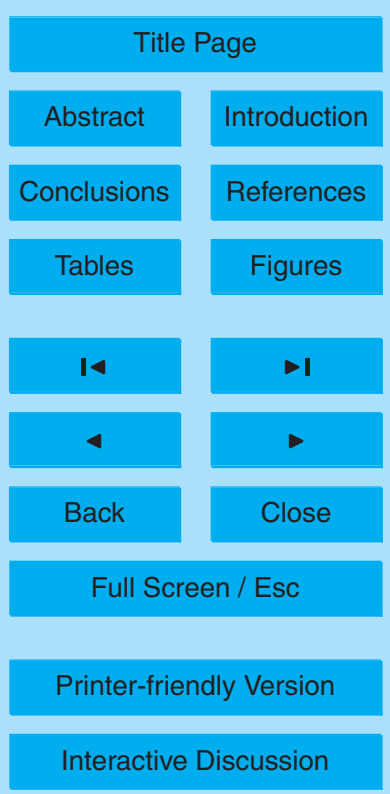

EGU 
(2001) performed another set of experiments using $\alpha$-pinene as an SOA precursor in the presence of NOx (two different initial conditions).

Kroll et al. (2005) measured SOA concentration in smog chambers using isoprene as precursor, with aqueous ammonium sulfate as initial seed. As our model is not yet 5 able to simulate heterogeneous phase reactions, the results of the experiments are only used to determine the general behavior of the model using isoprene as precursor, but not to make rigorous comparisons.

The Ito et al. (2007) chemical mechanism specifies an average rate constant for the reactions of the o-, $\mathrm{m}$ - and $\mathrm{p}$-xylene molecules, thus, this rate constant has been used 10 rather than that of the true $\mathrm{m}$-xylene rate. The difference between this average rate constant and that of $\mathrm{m}$-xylene is $3.75 \%$ at $298 \mathrm{~K}$.

Table 2 shows the initial conditions for each smog chamber experiment, as well as the measured SOA concentration at the end of the experiment, the simulated SOA concentration, and the percentage difference. The average error for all 20 smog chamber 15 simulations is $(32 \pm 63) \%$, but some of the experimental results are difficult to understand, with large differences in the final SOA concentration: A 295\% error between the model results and the measurements in PIN-303 (See Table 2 for a description of the cases) seems to be due to a problem in the smog chamber experiment, since the experiments PIN-101 and PIN-303 have very similar initial conditions, and only a small temperature difference ( $283 \mathrm{~K}$ and $303 \mathrm{~K}$, respectively); PIN-101 has a final SOA concentration of $89 \mu \mathrm{g} \mathrm{m}^{-3}$ and PIN-303 has only $20 \mu \mathrm{g} \mathrm{m}^{3}$. The differences in the vapor pressure at these temperatures, the change in reaction rates coefficients, and the variation in the partition coefficients are not enough to explain this difference.

If we exclude these two values (shown in italics in Table 2), the average error for 25 all the 18 remaining simulations is $(17 \pm 13) \%$, a reasonably small error, considering the uncertainties associated with the measurements and the parameters used in the model. A plot of the correlation between the measured and the simulated SOA concentrations is presented in Fig. 1. The correlation coefficient is equal to 0.996 , but cannot be used as a measurement of the robustness of the method as the plot covers a wide

\section{Development of a SOA formation mechanism}

L. E. Olcese et al.

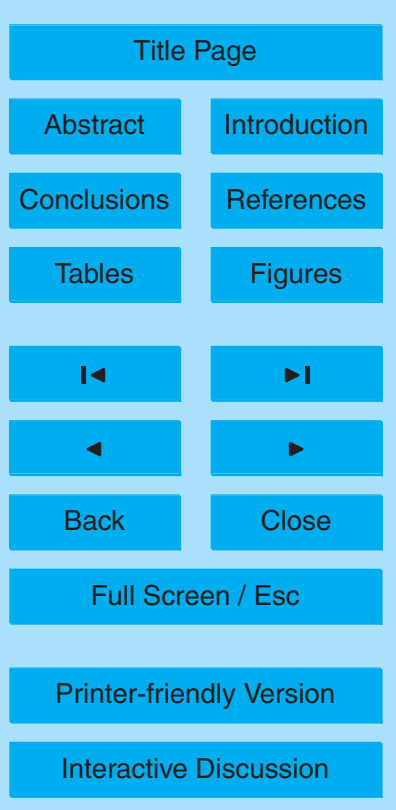

EGU 
range of SOA concentrations, with most of the points having low SOA concentrations. The correlation coefficient for all of the experiments, without including the two highest concentrations, is 0.792 .

We also performed simulations of nine different smog chamber experiments that 5 used isoprene as an SOA precursor (Kroll et al., 2005), under different temperatures, $\mathrm{O}_{3}$ and NOx concentrations and initial aqueous ammonium sulfate seed particles. These simulations produced an average error of 35\% (individual data not shown), but since the model does not include heterogeneous phase reactions, nor a different SOA formation mechanism for acidic particles, we did not pursue this mechanism further.

10 The errors obtained in the simulations with highest initial isoprene concentration were those with the higher errors.

\subsection{Comparison with ambient measurements}

The second set of simulations with our SOA formation mechanism used the experimental conditions in the TORCH 2003 experiment (Utembe et al., 2005; Johnson et al., 2006a, b). In this campaign, ambient concentrations of several species as well as organic aerosols were measured in Writtle, Essex, UK, approximately $40 \mathrm{~km}$ to the north east of central London. Measurements were made over a period of about one month, under different ambient conditions and plume originating sites. Initial conditions, trajectories and emissions were reported. Table 3 shows the trajectory arrival date, the average emissions of anthropogenic and biogenic VOC, the average emissions of NOx during the trajectory prior to the measurement site, and the observed and calculated $\mathrm{OA}$ concentrations.

The average error for the nine simulations was $(12 \pm 6) \%$. A plot of the correlation between the measured and the simulated SOA concentrations is presented in Fig. 2, 25 and gives a correlation coefficient equal to 0.942 . The average error of $12 \%$ is small, and is similar to that obtained in the smog chamber experiments.

These results can be compared directly to the trajectory calculation reported by Johnson et al. (2006a and b) on which it is based. Johnson et al. (2006a) found that
7, 8361-8393, 2007

Development of a SOA formation mechanism

L. E. Olcese et al.

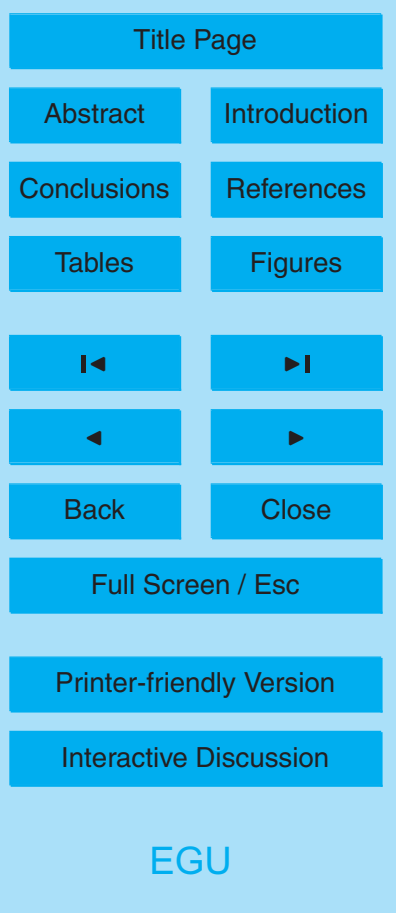


they were able to match the experimental results only if they assumed that gas-aerosol partition coefficients were higher than theoretical values by a factor of 500 . Here, results show reasonable agreement with observations without any adjustment to the partition coefficients derived from theory. The possible cause of this difference is the 5 inclusion in this work of different species in the partitioning scheme, mainly derivatives from biogenic precursors. Johnson et al. (2006b) reports that the average contribution of species derived from anthropogenic emissions to the simulated mass of SOA is $60 \%$, but our calculations showed that this contribution is only $25 \%$.

\subsection{Ambient simulations}

10 Two simulations were performed using realistic atmospheric concentrations and hourly emissions. The detailed initial conditions and average hourly emissions are presented in Tables $4 \mathrm{a}$ and $4 \mathrm{~b}$, as well as the final concentration of selected primary and secondary species. Both scenarios were run using the same initial concentrations of gas phase species, but with a different pattern of hourly emissions, that followed a diurnal cycle with peak anthropogenic emissions during morning and afternoon periods of high traffic in the urban-influenced case (based on average diurnal variations in EPA inventories, available at http://www.epa.gov/ttn/chief/net/1999inventory.html\#final3crit), and with the diurnal variation in the biogenic emissions in both the rural and the urbaninfluenced cases. Initial concentrations were based on typical conditions in rural northern Michigan, with total volatile organics equal to $5 \mathrm{ppbC}$.

A brief description of the initial conditions and emissions is:

- Rural site (Michigan, U.S.): Represents typical rural values for background concentrations and emissions that reflect conditions in northern Michigan. Emission rates were rural, and lower than would be found in more populated regions.

- Urban-influenced site (Pennsylvania and Ohio, U.S.): Represents average emissions (urban and rural combined) for a region corresponding roughly to the states

\section{Development of a SOA formation mechanism}

L. E. Olcese et al.

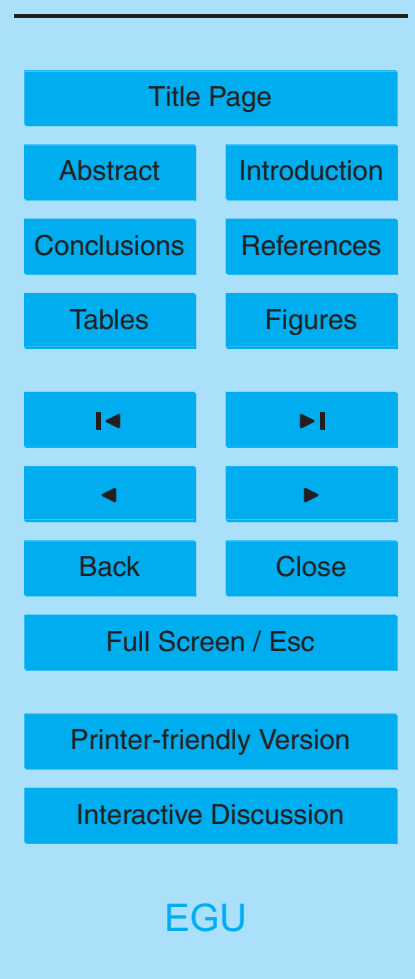


of Pennsylvania and Ohio, including large cities, power plants and large rural areas. Similar to the average emission rates across the eastern U.S.

Simulations were performed for a three-day period, beginning on 1 March. The initial POA concentration was $1 \mu \mathrm{g} \mathrm{m}^{-3}$, there were no additional POA emissions during the 5 simulation and the aerosol removal time constant was seven days. The calculations assume a constant mixing height of $5000 \mathrm{~m}$, typical of the height of the daytime mixed layer in the eastern U.S., a temperature of $25^{\circ} \mathrm{C}$ and no clouds.

Two different schemes were used, one allowing the evaporation of compounds from the aerosol phase (assuming continuous equilibrium with the gas phase) and another preventing evaporation. In the results presented here, only the non-evaporating scheme was used as this has been shown to better reproduce experimental measurements (Tsigaridis and Kanakidou, 2003). Results that assume continuous equilibrium produce less SOA by a factor of 1.1 .

The final concentration of relevant secondary compounds that partition to the aerosol phase is shown in Table 5, as well as the gas-phase concentrations of these compounds and their precursors. The total amount of SOA formed after the three days was $10.2 \mu \mathrm{g} \mathrm{m}^{-3}$ in the urban-influenced site and $7.2 \mu \mathrm{g} \mathrm{m}^{-3}$ in the rural site.

In Fig. 3 we show the fraction of each partitioning compound in the aerosol phase at the end of the three-day simulation. From the analysis of the plot, it is clear that in the aerosol phase, the secondary species formed from the biogenic compounds (PINT, ISNP, INPN, IALD) partition into the aerosol phase much more readily than those of anthropogenic origin (ACHO, A-DI, NITP), in both scenarios. The fraction of species formed from biogenic compounds account for about $90 \%$ of the total SOA mass in the urban influenced scenario and about $97 \%$ in the rural scenario.

A study of the dependence of the final SOA concentration on the VOC/NOx emissions ratio was carried out. When using the same initial VOC and NOx concentrations for both the urban-influenced and rural simulations, the final concentration of SOA is more sensitive to the change in the NOx emissions during the day than to the VOC emissions; an increase of $10 \%$ in the NOx emissions for the rural site produces $4 \%$

\section{Development of a SOA formation mechanism}

L. E. Olcese et al.

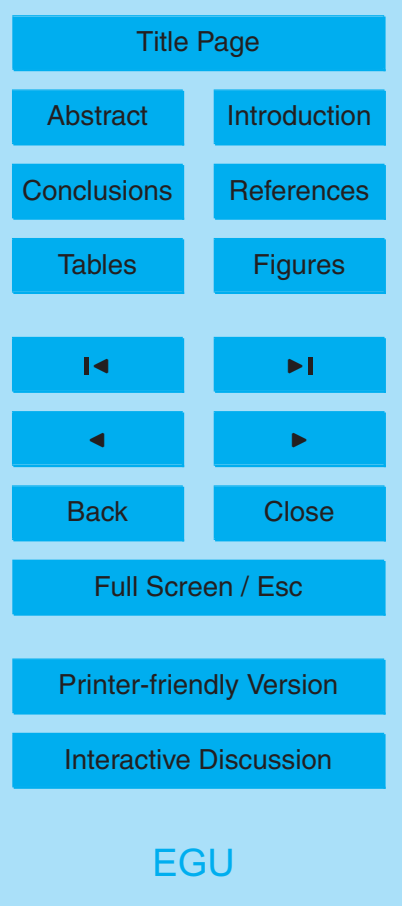


more SOA, and 3\% more for the urban-influenced site. In contrast, an increase of $10 \%$ in the VOC emissions leads to an increase of less than $1 \%$ in the mass of SOA produced in the both rural and urban-influenced sites. This suggests that the observed distribution of SOA may reflect the distribution of NOx, which is primarily anthropogenic 5 in origin, even when the SOA is formed from biogenic rather than anthropogenic VOC. This possibility was also mentioned by De Gouw et al. (2005) work, described below.

The second ambient simulation consists of a $0-d$ calculation with initial conditions derived from the measurement-based estimates of De Gouw et al. (2005). De Gouw et al. (2005) used measured ratios between individual anthropogenic VOC and $\mathrm{C}_{2} \mathrm{H}_{2}$ in 10 order to derive ambient $\mathrm{OH}$, age, and the initial concentrations of primary VOC. They similarly estimated the initial concentration of isoprene from measured concentrations of isoprene reaction products (methylvinyl ketone and methacrolein). Sources of other biogenic species were estimated based on correlations between measured reaction products and the derived isoprene. Terpenes were estimated from measured mixing 15 ratio of monoterpenes. However, these species did not form SOA in their calculation.

The study included a series of measurements of primary and secondary gas-phase organic species and organic aerosols during summer, 2002, from a ship located off the coast of Massachusetts and New Hampshire. The resulting measurements included an anthropogenic VOC that was representative of an average U.S. city, along with biogenic VOC reflecting the influence of forested regions in New England. There was evidence of direct influence of emissions from New York and Boston, but little evidence of impact from power plant emissions (De Gouw et al., 2005). The measured organic aerosols showed a correlation pattern that suggested that they were formed mainly through secondary photochemical production and were from anthropogenic sources. However, De

25 Gouw et al. (2005) found that the amount of measured SOA was significantly greater than the apparent removal of primary aromatic species that were the likely source of anthropogenic SOA. The evidence for anthropogenic rather than biogenic sources may also have been ambiguous if SOA formation from biogenic sources is more efficient in polluted regions than in rural locations.

\section{Development of a SOA formation mechanism}

L. E. Olcese et al.

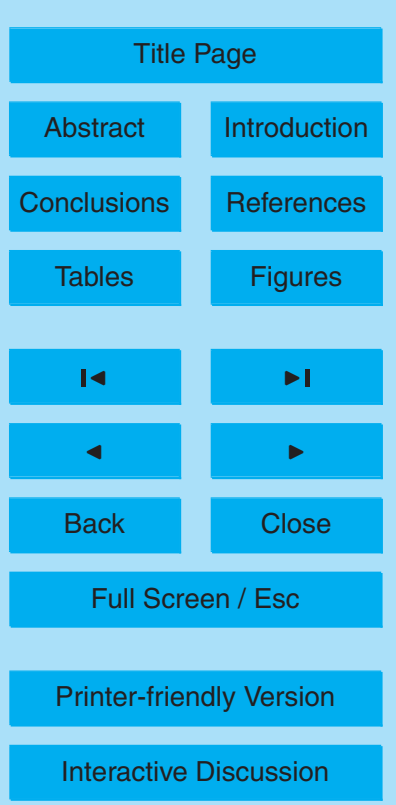

EGU 
We simulated these conditions using the initial estimates of primary anthropogenic and biogenic VOC for a period of $50 \mathrm{~h}$, matching the inferred time for photochemical processing. We also assumed initial concentrations of the measured oxygenated species based on the previous 3-day calculations of urban-influencedconditions in the 5 eastern U.S. Initial POA was set at $1 \mu \mathrm{g} \mathrm{m}^{-3}$, corresponding to the measured value from De Gouw et al. (2005) for air with photochemical age less than one hour. Initial conditions are shown in Tables $4 a$ and $b$.

Figure 4 shows the evolution of POM during the 50-h simulation with primary organic species derived directly from De Gouw et al. (2005). Results can be compared directly 10 with the evolution of POM as a function of photochemical age derived from measurements (Fig. 14c in De Gouw et al., 2005). Results compare closely with those reported by De Gouw et al. (2005). The main difference is due to the inclusion in our study of the diurnal cycle of radiation, since the de Gouw et al. work calculates concentrations using average rate constants and daily average $\mathrm{OH}$ concentrations. The final amount 15 of SOA formed after $50 \mathrm{~h}$ is similar in both cases; $7.2 \mu \mathrm{g} \mathrm{m}^{-3}$ in the Gouw et al. (2005) work and $7 \mu \mathrm{g} \mathrm{m}^{-3}$ in our model. The calculation shows a large increase in SOA during the first day of the simulation due to the initialization of gas-phase oxygenated intermediate compounds in our model. Our results showed that secondary aerosol formation from anthropogenic sources alone was unable to account for the observed $7 \mu \mathrm{g} \mathrm{m}^{-3}$ POM, a result that is consistent with De Gouw et al. (2005) However, our mechanism resulted in significant aerosol formation from biogenic sources (about $65 \%$ of the final SOA concentration), which resulted in total POM matching the observed value.

\section{Conclusions}

We have presented a chemical mechanism together with partitioning coefficients that 25 represents direct chemical pathways for formation os SOA from gas-phase species. The resulting mechanism has been tested in comparison with three sets of measurements: (i) a series of smog chamber experiments; (ii) the TORCH 2003 field campaign

\section{Development of a SOA formation mechanism}

L. E. Olcese et al.

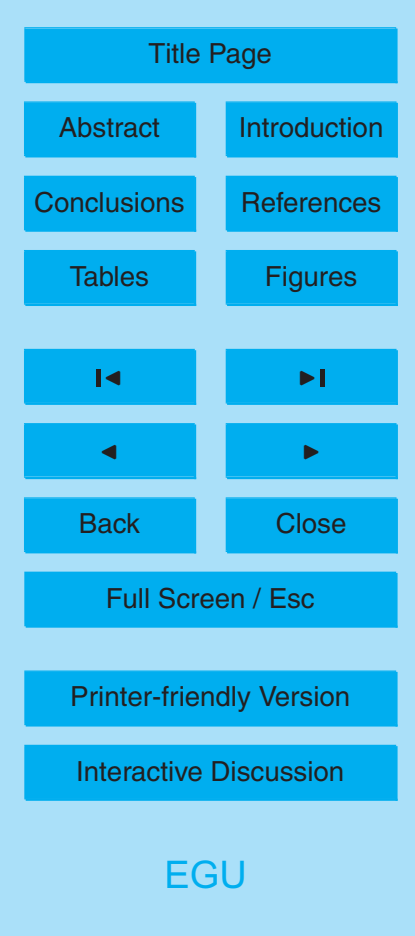


near London, and (iii) the New England Air Quality Study. In each case the resulting SOA formation compares reasonably well with measurements. In the case of TORCH, results represent a significant improvement over previous calculations.

The main advantage of this model, compared to other representations of SOA forma5 tion, is that the partitioning and stoichiometric coefficients are not fitted to experimental data, but calculated, making the model more flexible and able to include new compounds or to use new chemical mechanisms. The only data required are the species that can partition to the aerosol phase, and their vapor pressures (measured or estimated).

10 Calculations designed to represent conditions in the eastern U.S. suggested that secondary organic products derived from biogenic emissions are responsible for most of the mass of the secondary organic aerosols. This fact is in agreement with previous modeling results (Chung and Seinfeld, 2002). It may be possible that some anthropogenic sources of SOA are missing from our mechanism, since other mechanisms cannot reproduce recently measured results off of Asia (Heald et al., 2005) or from Mexico City (Volkamer et al., 2006). Our mechanism does not appear to include significantly larger anthropogenic source of SOA than previous mechanisms.

In the simulation based on the New England Air Quality Study the resulting SOA and its variation with photochemical age compared closely with values derived from

measurements. These results are consistent with the conclusion from De Gouw et al. (2005) that organics from anthropogenic sources are not sufficient to supply as much SOA as observed. In our calculation approximately $60 \%$ of the secondary organic aerosols are associated with biogenic emissions, while the remainder is from the oxidation of initial anthropogenic compounds.

From correlations between primary and secondary species, De Gouw et al. suggested that the measured aerosols were derived primarily from anthropogenic rather than biogenic sources, although the measured gas-phase species were not large enough to supply the observed SOA. Our results suggest that aerosols are formed mostly from biogenic organic sources under the influence of anthropogenic $\mathrm{NO}_{\mathrm{x}}$. $\mathrm{A}$

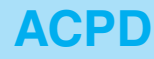

7, 8361-8393, 2007

\section{Development of a SOA formation mechanism}

L. E. Olcese et al.

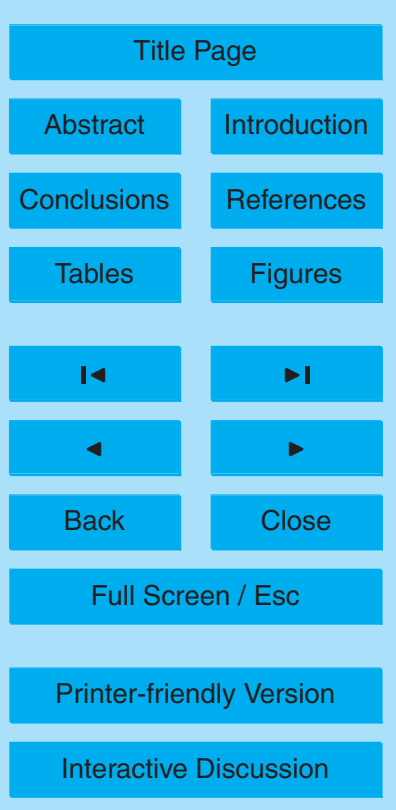

EGU 
further test of the mechanism in a 3-d simulation will be necessary to identify whether the pattern of variation of SOA found by De Gouw et al. (2005) might be produced by a combination of biogenic VOC and anthropogenic $\mathrm{NO}_{\mathrm{x}}$. The global amount of emissions of the different species that have the potential to react with an oxidant and then 5 form SOA is uncertain (Kanakidou et al, 2005), but several estimates of global VOC emissions are available.

Isoprene accounts for about half of all natural VOC (Volatile organic compounds) emissions; its estimated global emissions range between 250 and $750 \mathrm{TgCy}^{-1}$ (Wiedinmyer et al., 2004). Global emissions of terpenes (excluding isoprene) are $10127.4 \mathrm{Tgy}^{-1}$ (Guenther et al., 1995), although the SOA formation potential of the different terpenes is quite dissimilar.

The sum of the emissions of all the different anthropogenic aromatics species is estimated to be $15.8 \mathrm{Tgy}^{-1}$ (Olivier et al., 1999), and are mostly toluene and xylene. These emissions add up to about $10-15 \%$ of all anthropogenic NMVOC (non-methane volatile organic compounds) emissions.

An estimate of the annual global SOA production can be made by scaling the amount of SOA produced in two different three day simulations, using the rural and urbaninfluenced atmospheres. The scaling factor used was the quotient between the annual SOA estimates presented by Tsigaridis and Kanakidou (2003), and the results obtained from the rural and urban-influenced atmospheres, but using the two-product scheme from Tsigaridis and Kanakidou (2003).

Using the primary emissions mentioned above and the range reported for isoprene, the estimated SOA production is $35.2-235 \mathrm{Tg} \mathrm{y}^{-1}$, higher than other recent estimates (For example, Henze and Seinfeld, 2006 calculated $16.4 \mathrm{Tgy}^{-1}$, and Tsigaridis and 25 Kanakidou, 2003 calculated 2.5-46 $\mathrm{Tg} \mathrm{y}^{-1}$ ), but the Tsigaridis and Kanakidou estimate must be considered a lower limit, since SOA formation from $\mathrm{NO}_{3}$ reactions with all VOC and from $\mathrm{OH}$ oxidation with biogenic $\mathrm{VOC}$ was neglected. One important fact to note is that, although the isoprene has a low SOA yield, the great amount released to the atmosphere can play an important role in global SOA formation.

\section{Development of a SOA formation mechanism}

L. E. Olcese et al.

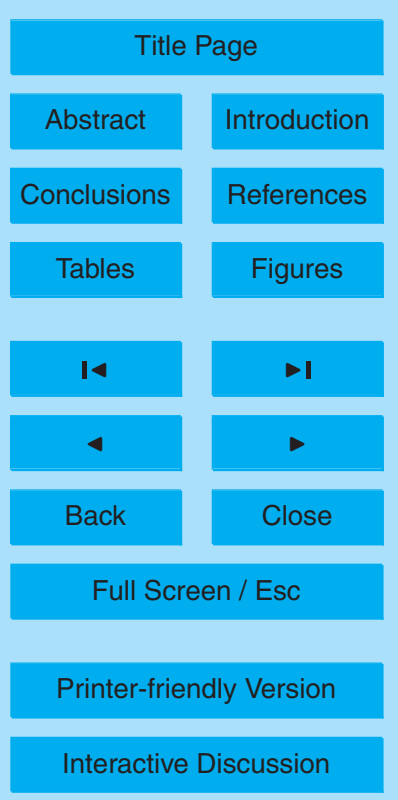

EGU 
Future work will include the development of a wet and dry removal process for SOA, based on the removal processes for aerosols in our global aerosol model. Other future improvements to the model include the addition of reactions in the aerosol and heterogeneous phase, such as dimerization and polymerization to simulate the process of 5 aerosol aging.

The SOA formation module will be incorporated into the IMPACT 3-D global chemical transport model. This model can be run in a chemistry only mode (Ito et al., 2006) or in a aerosol only mode (Liu et al., 2005), but without inclusion of secondary organic aerosol formation. In the future, we plan to couple these two operational modes and 10 then add the SOA formation mechanism, to simulate the concentrations of SOA on a global scale, with updated POM and BC emission inventories (Ito and Penner, 2005).

Acknowledgements. Support for this research was provided by a grant to J. E. Penner from the NASA GMI Program under contract NNG06GE78G, "Development of a Coupled AerosolChemistry Model". Additional support was provided to S. Sillman by the National Science

15 Foundation under grant No. 0454838. Any opinions, findings, and conclusions or recommendations expressed in this material are those of the author(s) and do not necessarily reflect the views of the National Science Foundation.

\section{References}

Bowman, F. H., Odum, J. R., Seinfeld, J. H., and Pandis, S. N.: Mathematical model for gasparticle partitioning of secondary organic aerosols, Environ. Sci. Technol., 31, 3921-3931, 1997.

Bowman, F. M. and Karamalegos, A. M.: Estimated Effects of Composition on Secondary Organic Aerosol Mass Concentrations, Environ. Sci. Technol., 36, 2701-2707, 2002.

Camredon, M. and Aumont, B.: Assessment of vapor pressure estimation methods for secondary organic aerosol modeling, Atmos. Environ., 40, 2105-2116, 2006.

Chung, S. H. and Seinfeld, J. H.: Global distribution and climate forcing of carbonaceous aerosols, J. Geophys. Res., 107, 4407-4440, 2002.

de Gouw, J. A., Middlebrook, A. M., Warneke, C., Goldan, P. D., Kuster, W. C., Roberts, J. M.,

Development of a SOA formation mechanism

L. E. Olcese et al.

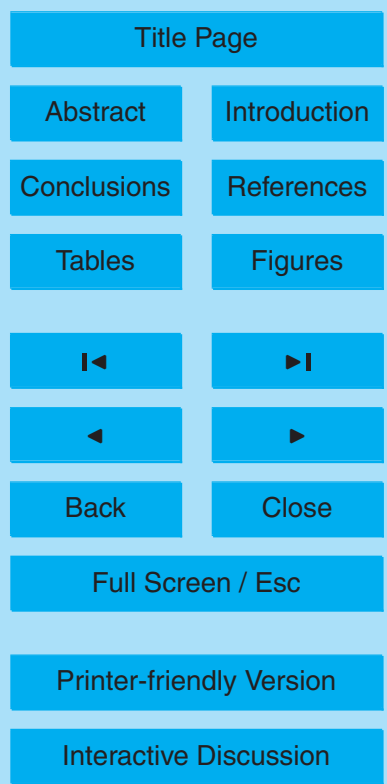


Fehsenfeld, F. C., Worsnop, D. R., Canagaratna, M. R., Pszenny, A. A. P., Keene, W. C., Marchewka, M., Bertman, S. B., and Bates, T. S.: Budget of organic carbon in a polluted atmosphere: Results from the New England Air Quality Study in 2002, J. Geophys. Res., 110, 16 305-16327, 2005.

5 Edney, E. O., Kleindienst, T. E., Jaoui, M., Lewandowski, M., Offenberg, J. H., Wang, W., and Claeys, M.: Formation of 2-methyl tetrols and 2-methylglyceric acid in secondary organic aerosol from laboratory irradiated isoprene/ $\mathrm{NOx} / \mathrm{SO}_{2} /$ air mixtures and their detection in ambient PM samples collected in the eastern United States, Atmos. Environ., 39, 5281-5289, 2005.

10 Griffin, R. J., Dabdub, D., and Seinfeld, J. H.: Secondary organic aerosol: I. Atmospheric chemical mechanism for production of molecular constituents, J. Geophys. Res., 107, 43324358, 2002.

Guenther, A., Hewitt, C. N., Erickson, D., Fall, R., Geron, C., Graedel, T., Harley, P., Klinger, L., Lerdau, M., McKay, W., Pierce, T., Scholes, B., Steinbrecher, R., Tallamraju, R., Taylor, J. and Zimmerman, P.: A global model of natural volatile organic compound emissions, J. Geophys. Res., 100, 8873-8892, 1995.

Heald, C. L., Jacob, D. J., Park, R. J., Russell, L. M., Huebert, B. J., Seinfeld, J. H., Liao, H., and Weber, R. J.: A large organic aerosol source in the free troposphere missing from current models, Geophys. Res. Lett., 32 , 1-4, 2005.

20 Henze, D. K. and Seinfeld, J. H.: Global secondary organic aerosol from isoprene oxidation, Geophys. Res. Lett., 33 , L09812, doi:10.1029/2006GL025976, 2006.

Hoffmann, T., Odum, J. R., Bowman, F., Collins, D., Klockow, D., Flagan, R. C., and Seinfeld, J. H.: Formation of organic aerosols from the oxidation of biogenic hydrocarbons, J. Atmos. Chem., 26, 189-222, 1997.

linuma, Y., Böge, O., Gnauk, T., and Herrmann, H.: Aerosolchamber study of the $\alpha$-pinene $/ \mathrm{O}_{3}$ reaction: influence of particle acidity on aerosol yields and products, Atmos. Environ., 38, 761-773, 2004.

Ito, A. and Penner, J. E.: Historical emissions of carbonaceous aerosols from biomass and fossil fuel burning for the period 1870-2000, Global Biogeochem. Cycles, GB2028, 1-14, $30 \quad 2005$

Ito, A., Sillman, S., and Penner, J. E.: Effects of additional non-methane volatile organic compounds, organic nitrates and direct emissions of oxygenated organic species on global tropospheric chemistry, J. Geophys. Res., 112, D06309. doi:10.1029/2005JD006556, 2007.

\section{Development of a SOA formation mechanism}

L. E. Olcese et al.

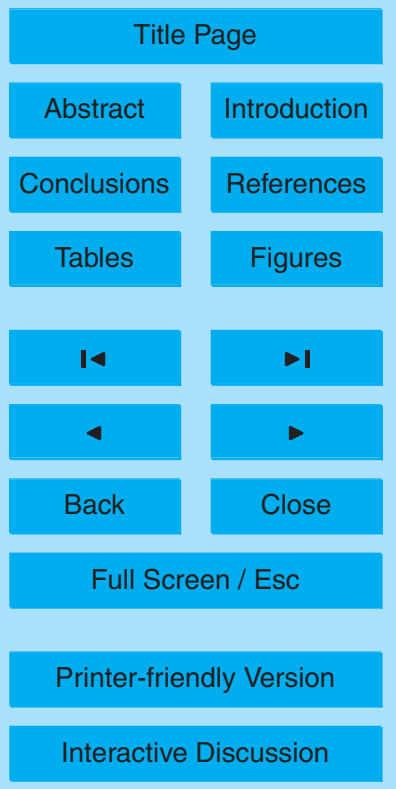


Johnson, D., Utembe, S. R., and Jenkin, M. E.: Simulating the detailed chemical composition of secondary organic aerosol formed on a regional scale during the TORCH 2003 campaign in the southern UK, Atmos. Chem. Phys., 6, 419-431, 2006b.

Johnson, D., Utembe, S. R., Jenkin, M. E., Derwent, R. G., Hayman, G. D., Alfarra, M. R., 5 Coe, $H_{\text {., }}$ and McFiggans, G.: Simulating regional scale secondary organic aerosol formation during the TORCH 2003 campaign in the southern UK, Atmos. Chem. Phys., 6, 403-418, $2006 a$.

Kalberer, M., Paulsen, R.D., Sax, M., Steinbacher, M., Dommen, J., Prevot, A. S. H., Fisseha, R., Weingartner, E., Frankevich, V., Zenobi, R., and Baltensperger, U.: Identification of polymers as major components of atmospheric organic aerosols, Science, 303, 1659-1662, 2004.

Kamens, R. M. and Jaoui, M.: Modeling aerosol formation from $\alpha$-pinene $+\mathrm{NO}$ in the presence of natural sunlight using gas-phase kinetics and gas-particle partitioning theory, Environ. Sci. Technol., 35, 1394-1405, 2001.

15 Kamens, R. M., Jang, M., Chien, C.-J., and Leach, K.: Aerosol formation from the reaction of $\alpha$-pinene and ozone using a gas phase kinetics-aerosol partitioning model, Environ. Sci. Technol., 33, 1430-1438, 1999.

Kanakidou, M., Seinfeld, J. H., Pandis, S. N., Barnes, I., Dentener, F. J., Facchini, M. C., van Dingenen, R., Ervens, B., Nenes, A., Nielsen, C. J., Swietlicki, E., Putaud, J.P., Balkanski, Y., Fuzzi, S., Horth, J., Moortgat, G. K., Winterhalter, R., Myhre, C. E. L., Tsigaridis, K., Vignati, E., Stephanou, E. G., and Wilson, J.: Organic aerosol and climate modelling: A review, Atmos Chem. Phys., 5, 1053-1123, 2005.

Kroll, J. H., Ng, N. L., Murphy, S. M., Flagan, R. C., and Seinfeld, J. H.: Secondary organic aerosol formation from isoprene photooxidation under high-NOx conditions, Geophys. Res. 25 Lett., 32, L18808, 1-4, 2005.

Liu, X., Penner, J. E., and Herzog, M.: Global modeling of aerosol dynamics: Model description, evaluation, and interactions between sulfate and nonsulfate aerosols, J. Geophys. Res, 111, D18206, doi:10.1029/2004JD005674, 2005.

Matsunaga, S. N., Wiedinmyer, C., Guenther, A. B., Orlando, J. J., Karl, T., Toohey, D. W., 30 Greenberg, J. P., and Kajii, Y.: Isoprene oxidation products are a significant atmospheric aerosol component, Atmos. Chem. Phys. Discuss., 5, 11143-11156, 2005.

Myrdal, P. B. and Yalkowsky, S. H.: Estimating pure component vapor pressures of complex organic molecules, Ind. Eng. Chem. Res., 36, 2494-2499, 1997.

\section{Development of a SOA formation mechanism}

L. E. Olcese et al.

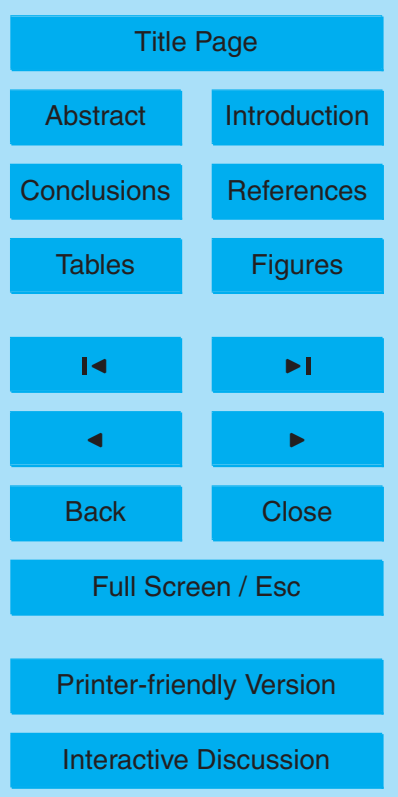


Olivier, J. G. J., Bloos, J. P. J., Berdowski, J. J. M., Visschedijk, A. J. H., and Bouwman, A. F.: A 1990 global emission inventory of anthropogenic sources of carbon monoxide on $1^{\circ} \times 1^{\circ}$ developed in the framework of EDGAR/GEIA, Chemosphere, Global Change Science, 1, 1-17, 1999.

5 Pandis, S. N., Paulson, S. E., Seinfeld, J. H., and Flagan, R. C.: Aerosol formation in the photooxidation of isoprene and $\beta$-pinene, Atmos. Environ., 25, 997-1008, 1991.

Pankow, J. F.: An absorption model of gas/particle partitioning of organic compounds in the atmosphere, Atmos. Environ., 28, 185-188, 1994b.

Pankow, J. F.: An absorption model of gas/particle partitioning involved in the formation of secondary organic aerosol, Atmos. Environ., 28, 189-193, 1994a.

Pun, B. K., Seigneur, C., and Lohman, K.: Modeling secondary organic aerosol formation via multiphase partitioning with molecular data, Environ. Sci. Technol., 40, 4722-4731, 2006.

Reid, R. C., Prausnitz, J. M., and Polling, B. E.: The properties of gases and liquids, Hill, New York, USA, 1987.

Sillman, S.: A numerical solution for the equations of tropospheric chemistry based on an analysis of sources and sinks of odd hydrogen, J. Geophys. Res., 96, 735-744, 1991.

Surratt, J. D., Murphy, S. M., Kroll, J. H., Ng, N. L., Hildebrandt, L., Sorooshian, A., Szmigielski, R., Vermeylen, R., Maenhaut, W., Claeys, M., Flagan, R. C., and Seinfeld, J. H.: Chemical Composition of Secondary Organic Aerosol Formed from the Photooxidation of Isoprene, J. Phys. Chem. A, 110, 9665-9690, 2006.

Takekawa, H., Minoura, H., and Yamazaki, S.: Temperature dependence of secondary organic aerosolformation by photooxidation of hydrocarbons, Atmos. Environ., 37, 3413-3424, 2003.

Tsigaridis, K. and Kanakidou M.: Global modeling of secondary organic aerosol in the troposphere: A sensitivity analysis, Atmos. Chem. Phys., 3, 1849-1869, 2003, http://www.atmos-chem-phys.net/3/1849/2003/.

Turpin, B. J. and Huntzicker, J. J.: Identifications of secondary organic aerosol episodes and quantification of primary and secondary organic aerosol concentration, Atmos. Environ., 29, 3527-3544, 1995.

Utembe, S. R., Jenkin, M. E., Derwent, R. G., Lewis, A. C., Hopkins, J. R., and Hamilton, J. F.: Modelling the ambient distribution of organic compounds during the August 2003 ozone episode in the southern UK, Faraday Discuss., 130, 311-326, 2005.

van Donkelaar, A., Martin, R. V., Park, R. J., Heald, C. L., Fu, T.-M., Liao, H., and Guenther, A.: Model evidence for a significant source of secondary organic aerosol from isoprene, Atmos.

\section{Development of a SOA formation mechanism}

L. E. Olcese et al.

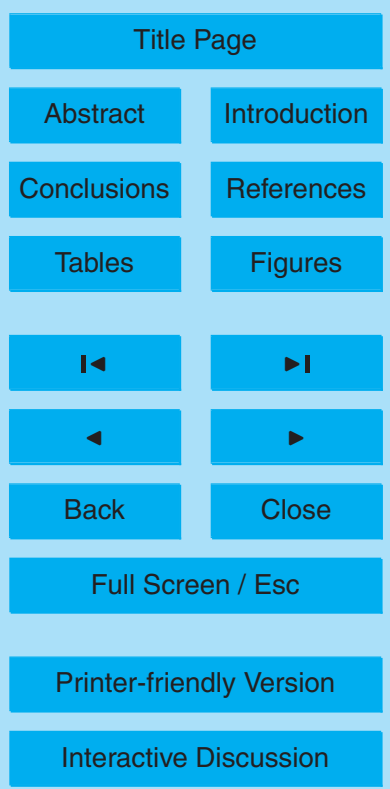


Envir., 41, 1267-1275, 2007.

Volkamer, R., Jimenez, J. L., San Martini, F., Dzepina, K., Zhang, Q., Salcedo, D., Molina, L. T. D., Worsnop, R., and Molina, M. J.: Secondary organic aerosol formation from anthropogenic air pollution: Rapid and higher than expected, Geophys. Res. Lett., 33, L17811, doi:10.1029/2006GL026899, 2006.

Wiedinmyer, C., Guenther, A., Harley, P., Hewitt, N., Geron, C., Artaxo, P., Steinbrecher, R., and Rasmussen, R.: Global Organic Emissions from Vegetation, in: Emissions of Atmospheric Trace Compounds, edited by: Granier, C., Artaxo, P., and Reeves, C., Kluwer Academic Publishers, Dordrecht, The Netherlands, 115-170, 2004.

10 Zhang, Y., Pun, B., Vijayaraghavan, K., Wu, S.-Y., Seigneur, C., Pandis, S. N., Jacobson, M. Z., Nenes, A., and Seinfeld, J. H.: Development and application of the Model of Aerosol Dynamics, Reaction, Ionization, and Dissolution (MADRID), J. Geophys. Res, 109, D06302, doi:10.1029/2003JD003501, 2004.

\section{ACPD}

7, 8361-8393, 2007

\section{Development of a SOA formation mechanism}

L. E. Olcese et al.

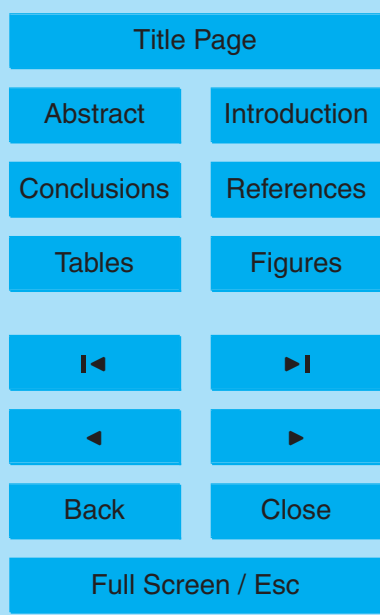

Printer-friendly Version

Interactive Discussion 
Table 1. List of species that can partition to the aerosol phase, chosen depending on their chemical structure.

\begin{tabular}{|c|c|c|c|}
\hline Name & $\begin{array}{l}\text { Partition in significant } \\
\text { quantities? }\end{array}$ & $\begin{array}{l}\text { Partitioning coefficient at } 298 \mathrm{~K} \\
\text { and } 1 \mathrm{~atm}\left[\mathrm{~m}^{3} \mu \mathrm{g}^{-1}\right]\end{array}$ & Description \\
\hline A-DI & Yes & $2.01 \times 10^{-3}$ & $\mathrm{C}_{6} \mathrm{H}_{5} \mathrm{OH}(\mathrm{OH}) \mathrm{CHO}$ \\
\hline $\mathrm{ACHO}$ & Yes & $3.29 \times 10^{-1}$ & $\mathrm{C}_{6} \mathrm{H}_{5} \mathrm{CHO}$ \\
\hline AD2P & No & $2.71 \times 10^{13}$ & $\mathrm{C}_{6} \mathrm{H}_{5}\left(\mathrm{CH}_{3}\right) \mathrm{OH}(\mathrm{OH}) \mathrm{OOH}$ \\
\hline AP & No & $9.18 \times 10^{14}$ & $\mathrm{C}_{6} \mathrm{H}_{5} \mathrm{OH}(\mathrm{OH}) \mathrm{CO}_{3} \mathrm{H}$ \\
\hline APAN & No & $1.01 \times 10^{11}$ & $\mathrm{C}_{6} \mathrm{H}_{5} \mathrm{OH}(\mathrm{OH}) \mathrm{CO}_{3} \mathrm{NO}_{2}$ \\
\hline DPAN & No & $1.50 \times 10^{0}$ & $\mathrm{CHOCH}=\mathrm{CHCO}_{3} \mathrm{NO}_{2}$ \\
\hline GPAN & No & $5.19 \times 10^{0}$ & $\mathrm{HOCH}_{2} \mathrm{C}(\mathrm{O}) \mathrm{OONO}_{2}$ \\
\hline IALD & Yes & $1.26 \times 10^{2}$ & $\mathrm{HOCH}_{2} \mathrm{C}\left(\mathrm{CH}_{3}\right)=\mathrm{CHCHO}$ \\
\hline IAP & No & $1.07 \times 10^{14}$ & $\mathrm{HOCH}_{2} \mathrm{C}\left(\mathrm{CH}_{3}\right)(\mathrm{OOH}) \mathrm{CH}(\mathrm{OH}) \mathrm{CHO}$ \\
\hline INPN & Yes & $4.89 \times 10^{3}$ & $\mathrm{NO}_{2} \mathrm{OCH}_{2} \mathrm{C}(\mathrm{OOH})\left(\mathrm{CH}_{3}\right) \mathrm{CH}=\mathrm{CH}_{2}$ \\
\hline ISNP & Yes & $1.19 \times 10^{15}$ & $\mathrm{HOCH}_{2} \mathrm{C}(\mathrm{OOH})\left(\mathrm{CH}_{3}\right) \mathrm{CH}\left(\mathrm{ONO}_{2}\right) \mathrm{CH}_{2} \mathrm{OH}$ \\
\hline LIP & No & $3.34 \times 10^{10}$ & $\mathrm{HOC}_{10} \mathrm{H}_{16} \mathrm{OOH}$ \\
\hline MRP & No & $3.14 \times 10^{7}$ & $\mathrm{HOCH}_{2} \mathrm{C}(\mathrm{OOH})\left(\mathrm{CH}_{3}\right) \mathrm{CHO}$ \\
\hline NITP & Yes & $4.38 \times 10^{0}$ & $\mathrm{C}_{6} \mathrm{H}_{5} \mathrm{ONO}_{2}$ \\
\hline PINT & Yes & $1.76 \times 10^{8}$ & $\mathrm{ONO}_{2} \mathrm{C}_{10} \mathrm{H}_{16} \mathrm{OOH}$ \\
\hline PIP & No & $1.05 \times 10^{9}$ & $\mathrm{HOC}_{10} \mathrm{H}_{16} \mathrm{OOH}$ \\
\hline VRP & No & $1.48 \times 10^{8}$ & $\mathrm{HOCH}_{2} \mathrm{CH}(\mathrm{OOH}) \mathrm{C}(\mathrm{O}) \mathrm{CH}_{3}$ \\
\hline XAP & No & $6.14 \times 10^{5}$ & $\mathrm{CH}_{3} \mathrm{COCH}=\mathrm{CH}(\mathrm{O}) \mathrm{OOH}$ \\
\hline XPAN & No & $1.84 \times 10^{1}$ & $\mathrm{CH}_{3} \mathrm{COCH}=\mathrm{CHCO}_{3} \mathrm{NO}_{2}$ \\
\hline YAP & No & $1.15 \times 10^{2}$ & $\mathrm{CHOCH}=\mathrm{C}\left(\mathrm{CH}_{3}\right) \mathrm{C}(\mathrm{O}) \mathrm{OOH}$ \\
\hline YPAN & No & $8.54 \times 10^{0}$ & $\mathrm{CHOCH}=\mathrm{C}\left(\mathrm{CH}_{3}\right) \mathrm{CO}_{3} \mathrm{NO}_{2}$ \\
\hline ZAP & No & $2.27 \times 10^{4}$ & $\mathrm{CHOC}\left(\mathrm{CH}_{3}\right)=\mathrm{CHC}(\mathrm{O}) \mathrm{OOH}$ \\
\hline ZPAN & No & $8.53 \times 10^{0}$ & $\mathrm{CHOC}\left(\mathrm{CH}_{3}\right)=\mathrm{CHCO}_{3} \mathrm{NO}_{2}$ \\
\hline
\end{tabular}

\section{ACPD}

7, 8361-8393, 2007

\section{Development of a SOA formation mechanism}

L. E. Olcese et al.

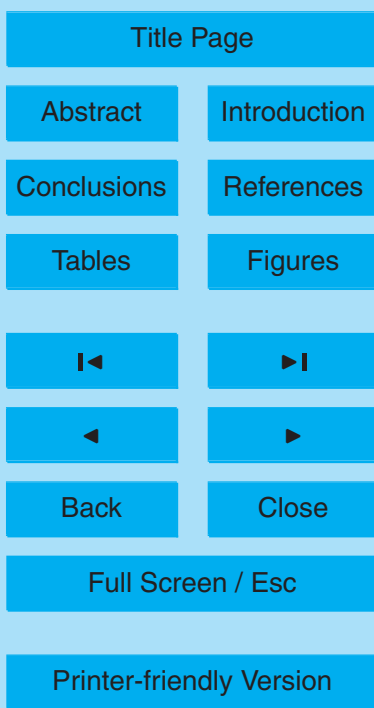

Interactive Discussion 


\section{ACPD}

Table 2. Comparison with results from smog chamber experiments.

\begin{tabular}{|c|c|c|c|c|c|c|c|c|}
\hline Name & $\begin{array}{l}\mathrm{HC} \\
{[\mathrm{ppm}]}\end{array}$ & $\begin{array}{l}\mathrm{NO} \\
\text { [ppm] }\end{array}$ & $\begin{array}{l}\mathrm{NO}_{2} \\
{[\mathrm{ppm}]}\end{array}$ & $\begin{array}{l}\text { Temp } \\
{[\mathrm{K}]}\end{array}$ & $\begin{array}{l}\text { Time } \\
\text { [h] }\end{array}$ & $\begin{array}{l}\text { Measured } \\
\text { SOA } \\
{\left[\mu \mathrm{g} \mathrm{m}^{-3}\right]}\end{array}$ & $\begin{array}{l}\text { Simulated } \\
\text { SOA } \\
{\left[\mu \mathrm{g} \mathrm{m}^{-3}\right]}\end{array}$ & Difference \\
\hline$P I N-101^{a}$ & $\alpha$-Pinene -0.100 & 0.053 & 0.028 & 283 & 4 & 89 & 100 & $12 \%$ \\
\hline $\mathrm{PIN}-102^{\mathrm{a}}$ & $\alpha$-Pinene -0.081 & 0.043 & 0.021 & 283 & 4 & 65 & 84 & $30 \%$ \\
\hline$P I N-103^{a}$ & $\alpha$-Pinene -0.055 & 0.030 & 0.025 & 283 & 4 & 36 & 39 & $9 \%$ \\
\hline PIN-301 a & $\alpha$-Pinene -0.196 & 0.102 & 0.050 & 303 & 4 & 95 & 137 & $44 \%$ \\
\hline PIN-302 ${ }^{a}$ & $\alpha$-Pinene -0.146 & 0.080 & 0.039 & 303 & 4 & 58 & 52 & $10 \%$ \\
\hline$P I N-303^{a}$ & $\alpha$-Pinene -0.093 & 0.054 & 0.031 & 303 & 4 & 20 & 79 & $295 \%$ \\
\hline TOL-101 ${ }^{a}$ & Toluene $-2.64 / \mathrm{C}_{3} \mathrm{H}_{6}-1.0$ & 0.118 & 0.116 & 283 & 4 & 84 & 95 & $13 \%$ \\
\hline TOL-102 ${ }^{a}$ & Toluene $-3.25 / \mathrm{C}_{3} \mathrm{H}_{6}-1.1$ & 0.142 & 0.142 & 283 & 4 & 97 & 112 & $15 \%$ \\
\hline TOL-103 ${ }^{a}$ & Toluene $-2.20 / \mathrm{C}_{3} \mathrm{H}_{6}-1.1$ & 0.094 & 0.092 & 283 & 4 & 61 & 74 & $22 \%$ \\
\hline TOL-301 & Toluene - $4.33 / \mathrm{C}_{3} \mathrm{H}_{6}-0.9$ & 0.211 & 0.202 & 303 & 4 & 92 & 109 & $18 \%$ \\
\hline TOL-302 ${ }^{a}$ & Toluene - $3.35 / \mathrm{C}_{3} \mathrm{H}_{6}-1.0$ & 0.169 & 0.168 & 303 & 4 & 57 & 82 & $43 \%$ \\
\hline TOL-303 ${ }^{\mathrm{a}}$ & Toluene $-2.61 / \mathrm{C}_{3} \mathrm{H}_{6}-1.1$ & 0.150 & 0.129 & 303 & 4 & 29 & 32 & $11 \%$ \\
\hline$X Y L-101^{a}$ & m-Xylene $-2.19 / \mathrm{C}_{3} \mathrm{H}_{6}-1.1$ & 0.098 & 0.087 & 283 & 4 & 130 & 99 & $24 \%$ \\
\hline$X Y L-102^{a}$ & m-Xylene - $1.57 / \mathrm{C}_{3} \mathrm{H}_{6}-1.2$ & 0.073 & 0.074 & 283 & 4 & 69 & 76 & $10 \%$ \\
\hline$X Y L-103^{a}$ & m-Xylene - $1.12 / \mathrm{C}_{3} \mathrm{H}_{6}-1.0$ & 0.062 & 0.062 & 283 & 4 & 40 & 44 & $9 \%$ \\
\hline$X Y L-301^{a}$ & m-Xylene $-3.13 / \mathrm{C}_{3} \mathrm{H}_{6}-1.0$ & 0.153 & 0.139 & 303 & 4 & 123 & 150 & $22 \%$ \\
\hline$X Y L-302^{a}$ & m-Xylene $-1.98 / \mathrm{C}_{3} \mathrm{H}_{6}-1.0$ & 0.100 & 0.096 & 303 & 4 & 43 & 43 & $1 \%$ \\
\hline$X Y L-303^{a}$ & $\mathrm{~m}$-Xylene $-2.83 / \mathrm{C}_{3} \mathrm{H}_{6}-1.0$ & 0.144 & 0.131 & 303 & 4 & 98 & 106 & $8 \%$ \\
\hline 6/9/99: light, $\mathrm{NOx}{ }^{\mathrm{b}}$ & $\alpha-$ Pinene -0.98 & 0.43 & 0.002 & $295-315$ & 3.6 & 550 & 576 & $5 \%$ \\
\hline 10/30/99: light, NOx ${ }^{b}$ & $\alpha$-Pinene -0.94 & 0.485 & 0.002 & $300-308$ & 3.6 & 1000 & 993 & $1 \%$ \\
\hline
\end{tabular}

\section{Development of a SOA formation mechanism}

L. E. Olcese et al.

${ }^{a}$ Measured by Takekawa et al. (2003)

${ }^{\mathrm{b}}$ Measured by Kamens et al. (1999)

The experiments in italics are not included in the calculation of the average error due to inconsistencies in its values.

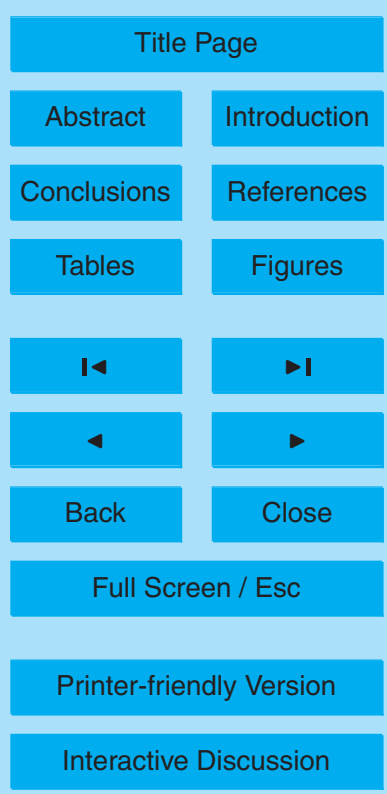




\section{ACPD}

7, 8361-8393, 2007

\section{Development of a SOA formation mechanism}

Table 3. Comparison with experimental results in the TORCH 2003 campaign.

\begin{tabular}{|c|c|c|c|c|c|c|}
\hline $\begin{array}{l}\text { Trajectory arrival } \\
\text { date }\end{array}$ & $\begin{array}{l}\text { Average emission of } \\
\text { anthopogenic VOC } \\
{\left[\mu \mathrm{g} \mathrm{m}^{-2} \mathrm{~h}^{-1}\right]}\end{array}$ & $\begin{array}{l}\text { Average emission of } \\
\text { biogenic VOC } \\
{\left[\mu \mathrm{g} \mathrm{m}^{-2} \mathrm{~h}^{-1}\right]}\end{array}$ & $\begin{array}{l}\text { Average emis- } \\
\text { sion of } \mathrm{NOx} \\
{\left[\mu \mathrm{g} \mathrm{m}^{-2} \mathrm{~h}^{-1}\right]}\end{array}$ & $\begin{array}{l}\text { Observed OA } \\
{\left[\mu \mathrm{g} \mathrm{m}^{-3}\right]}\end{array}$ & $\begin{array}{l}\text { Simulated OA } \\
{\left[\mu \mathrm{g} \mathrm{m}^{-3}\right]}\end{array}$ & Difference \\
\hline July 07, 2003 & 234 & 9.08 & 243 & 1.91 & 1.54 & $19 \%$ \\
\hline Aug 02, 2003 & 496 & 21.8 & 403 & 3.64 & 2.79 & $23 \%$ \\
\hline Aug 04,2003 & 349 & 23.4 & 323 & 4.02 & 3.40 & $15 \%$ \\
\hline Aug 06, 2003 & 1102 & 102 & 941 & 6.92 & 7.95 & $15 \%$ \\
\hline Aug 08, 2003 & 189 & 28.4 & 306 & 5.52 & 4.86 & $12 \%$ \\
\hline Aug 16, 2003 & 96 & 12.2 & 80.2 & 0.84 & 0.76 & $9 \%$ \\
\hline Aug 18, 2003 & 507 & 14.7 & 354 & 2.78 & 2.91 & $5 \%$ \\
\hline Aug 19, 2003 & 138 & 10.9 & 214 & 1.24 & 1.20 & $4 \%$ \\
\hline Aug 21, 2003 & 195 & 8.26 & 240 & 0.93 & 1.02 & $10 \%$ \\
\hline
\end{tabular}

Title Page

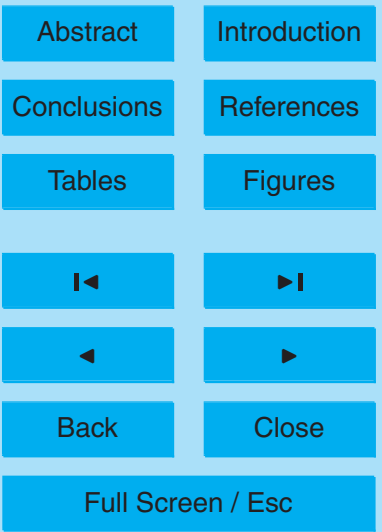

Printer-friendly Version

Interactive Discussion 
Table 4a. Initial concentrations, hourly emissions and final concentrations for the three-day rural simulation.

\begin{tabular}{|c|c|c|c|}
\hline Compound & $\begin{array}{l}\text { Initial } \\
\text { concentration } \\
{\left[\text { molec } \mathrm{cm}^{-3}\right]}\end{array}$ & $\begin{array}{l}\text { Average hourly } \\
\text { emission } \\
{\left[\text { molec } \mathrm{cm}^{-2}\right]}\end{array}$ & $\begin{array}{l}\text { Final } \\
\text { concentration } \\
{\left[\text { molec } \mathrm{cm}^{-3}\right]}\end{array}$ \\
\hline $\mathrm{O}_{3}$ & $9.4 \times 10^{11}$ & 0 & $2.7 \times 10^{11}$ \\
\hline $\mathrm{NO}_{2}$ & $3.0 \times 10^{8}$ & $1.5 \times 10^{9}$ & $5.2 \times 10^{9}$ \\
\hline NO & $3.0 \times 10^{8}$ & $3.1 \times 10^{10}$ & $1.1 \times 10^{7}$ \\
\hline Acetone & $2.0 \times 10^{9}$ & $2.6 \times 10^{8}$ & $2.7 \times 10^{9}$ \\
\hline Benzaldehyde & 0 & 0 & $1.4 \times 10^{3}$ \\
\hline Formic acid & 0 & 0 & $2.5 \times 10^{9}$ \\
\hline Acetic acid & 0 & 0 & $9.1 \times 10^{9}$ \\
\hline Acetaldehyde & $1.0 \times 10^{8}$ & $1.5 \times 10^{8}$ & $5.6 \times 10^{10}$ \\
\hline Alkanes C 4-5 & $2.0 \times 10^{8}$ & $8.3 \times 10^{9}$ & $1.4 \times 10^{10}$ \\
\hline Alkanes C 6-8 & $2.0 \times 10^{6}$ & $4.1 \times 10^{9}$ & $6.8 \times 10^{9}$ \\
\hline$\alpha$-pinene & $1.0 \times 10^{9}$ & $1.0 \times 10^{10}$ & $1.5 \times 10^{9}$ \\
\hline Benzene & $2.0 \times 10^{7}$ & $4.7 \times 10^{9}$ & $8.1 \times 10^{9}$ \\
\hline Trans-2-butene & 0 & $8.5 \times 10^{8}$ & $5.1 \times 10^{7}$ \\
\hline Ethane & $2.0 \times 10^{8}$ & $5.0 \times 10^{8}$ & $1.1 \times 10^{9}$ \\
\hline Propane & $2.0 \times 10^{7}$ & $1.6 \times 10^{9}$ & $2.8 \times 10^{9}$ \\
\hline Cresol & 0 & 0 & $9.7 \times 10^{6}$ \\
\hline Dicarbonyl & 0 & 0 & $2.0 \times 10^{7}$ \\
\hline Dimethyl phenol & 0 & 0 & $5.1 \times 10^{7}$ \\
\hline Ethanol & 0 & 0 & $9.5 \times 10^{10}$ \\
\hline Ethene & $1.0 \times 10^{6}$ & $2.8 \times 10^{9}$ & $4.2 \times 10^{9}$ \\
\hline Glycoaldehyde & 0 & 0 & $6.4 \times 10^{9}$ \\
\hline Glyoxal & 0 & 0 & $2.8 \times 10^{8}$ \\
\hline Hydroxyacetone & 0 & 0 & $3.7 \times 10^{10}$ \\
\hline Formaldeyhde & $1.5 \times 10^{9}$ & $7.4 \times 10^{8}$ & $4.5 \times 10^{11}$ \\
\hline Isoprene nitrate & 0 & 0 & $5.4 \times 10^{9}$ \\
\hline Isoprene & $1.0 \times 10^{9}$ & $4.0 \times 10^{12}$ & $4.70 \times 10^{11}$ \\
\hline Limonene & $1.0 \times 10^{9}$ & $1.0 \times 10^{10}$ & $6.1 \times 10^{8}$ \\
\hline Methacrolein & 0 & 0 & $2.1 \times 10^{11}$ \\
\hline Ketones C > 3 & $1.0 \times 10^{8}$ & $2.6 \times 10^{8}$ & $1.2 \times 10^{10}$ \\
\hline Methylglyoxal & 0 & 0 & $2.2 \times 10^{10}$ \\
\hline Methanol & 0 & 0 & $1.3 \times 10^{11}$ \\
\hline Methylhydroperoxide & 0 & 0 & $1.8 \times 10^{10}$ \\
\hline Peroxymethacryloyl nitrate & 0 & 0 & $8.5 \times 10^{9}$ \\
\hline Methylvinylketone & 0 & 0 & $9.9 \times 10^{10}$ \\
\hline Benzyl nirate & 0 & 0 & $8.8 \times 10^{3}$ \\
\hline PeroxyacetyInitrate & $7.5 \times 10^{9}$ & 0 & $3.6 \times 10^{8}$ \\
\hline Phenol & 0 & 0 & $1.3 \times 10^{7}$ \\
\hline Peroxypropionylnitrate & $5.0 \times 10^{8}$ & 0 & $1.4 \times 10^{7}$ \\
\hline Alkenes $\mathrm{C}>4$ & 0 & $2.2 \times 10^{9}$ & $3.0 \times 10^{10}$ \\
\hline Aldehydes C > 2 & $2.0 \times 10^{7}$ & $5.0 \times 10^{7}$ & $1.7 \times 10^{9}$ \\
\hline Higher order organic acid & 0 & 0 & $1.5 \times 10^{10}$ \\
\hline Alcohols $\mathrm{C}>2$ & 0 & 0 & $4.2 \times 10^{8}$ \\
\hline Toluene & $2.0 \times 10^{6}$ & $2.2 \times 10^{9}$ & $3.8 \times 10^{9}$ \\
\hline m-xylene & 0 & $2.2 \times 10^{9}$ & $3.3 \times 10^{9}$ \\
\hline
\end{tabular}

ACPD

7, 8361-8393, 2007

\section{Development of a SOA formation mechanism}

L. E. Olcese et al.

Title Page

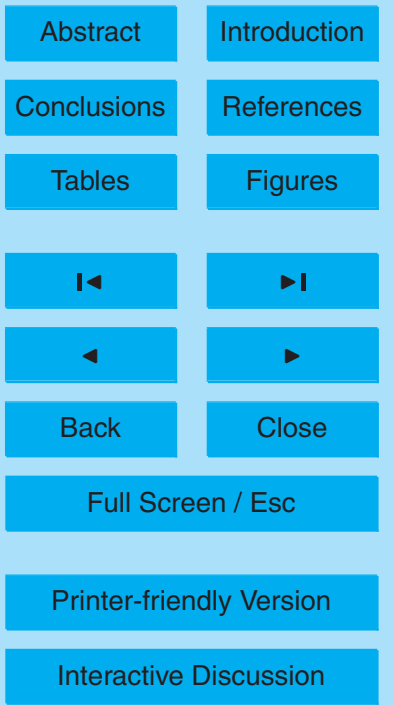


Table 4b. Initial concentrations, hourly emissions and final concentrations for the three-day urban-influenced simulation.

\begin{tabular}{|c|c|c|c|}
\hline Compound & $\begin{array}{l}\text { Initial } \\
\text { concentration } \\
{\left[\text { molec } \mathrm{cm}^{-3}\right]}\end{array}$ & $\begin{array}{l}\text { Average hourly } \\
\text { emission } \\
{\left[\text { molec } \mathrm{cm}^{-2} \text { ] }\right.}\end{array}$ & $\begin{array}{l}\text { Final } \\
\text { concentration } \\
{\left[\text { molec } \mathrm{cm}^{-3}\right]}\end{array}$ \\
\hline $\mathrm{O}_{3}$ & $9.4 \times 10^{11}$ & 0 & $1.1 \times 10^{12}$ \\
\hline $\mathrm{NO}_{2}$ & $3.0 \times 10^{8}$ & $1.5 \times 10^{10}$ & $6.8 \times 10^{10}$ \\
\hline NO & $3.0 \times 10^{8}$ & $4.6 \times 10^{11}$ & $4.5 \times 10^{7}$ \\
\hline Acetone & $2.0 \times 10^{9}$ & $2.0 \times 10^{9}$ & $2.2 \times 10^{10}$ \\
\hline Benzaldehyde & 0 & 0 & $1.2 \times 10^{5}$ \\
\hline Formic acid & 0 & 0 & $2.2 \times 10^{9}$ \\
\hline Acetic acid & 0 & 0 & $6.2 \times 10^{8}$ \\
\hline Acetaldehyde & $1.0 \times 10^{8}$ & $9.1 \times 10^{8}$ & $3.3 \times 10^{10}$ \\
\hline Alkanes C 4-5 & $2.0 \times 10^{8}$ & $6.2 \times 10^{10}$ & $7.6 \times 10^{10}$ \\
\hline Alkanes C 6-8 & $2.0 \times 10^{6}$ & $3.1 \times 10^{10}$ & $2.7 \times 10^{10}$ \\
\hline$\alpha$-pinene & $1.0 \times 10^{9}$ & $1.0 \times 10^{10}$ & $9.5 \times 10^{6}$ \\
\hline Benzene & $2.0 \times 10^{7}$ & $4.3 \times 10^{10}$ & $6.4 \times 10^{10}$ \\
\hline Trans-2-butene & 0 & $5.3 \times 10^{9}$ & $5.9 \times 10^{7}$ \\
\hline Ethane & $2.0 \times 10^{8}$ & $4.0 \times 10^{9}$ & $6.9 \times 10^{9}$ \\
\hline Propane & $2.0 \times 10^{7}$ & $1.2 \times 10^{10}$ & $1.8 \times 10^{10}$ \\
\hline Cresol & 0 & 0 & $2.4 \times 10^{4}$ \\
\hline Dicarbonyl & 0 & 0 & $2.2 \times 10^{9}$ \\
\hline Dimethyl phenol & 0 & 0 & $2.4 \times 10^{4}$ \\
\hline Ethanol & 0 & 0 & $9.5 \times 10^{8}$ \\
\hline Ethene & $1.0 \times 10^{6}$ & $3.4 \times 10^{10}$ & $2.2 \times 10^{10}$ \\
\hline Glycoaldehyde & 0 & 0 & $1.6 \times 10^{10}$ \\
\hline Glyoxal & 0 & 0 & $8.5 \times 10^{9}$ \\
\hline Hydroxyacetone & 0 & 0 & $1.7 \times 10^{10}$ \\
\hline Formaldeyhde & $1.5 \times 10^{9}$ & $8.1 \times 10^{9}$ & $1.3 \times 10^{11}$ \\
\hline Isoprene nitrate & 0 & 0 & $2.6 \times 10^{9}$ \\
\hline Isoprene & $1.0 \times 10^{9}$ & $4.0 \times 10^{11}$ & $2.23 \times 10^{10}$ \\
\hline Limonene & $1.0 \times 10^{9}$ & $1.0 \times 10^{10}$ & $4.8 \times 10^{6}$ \\
\hline Methacrolein & 0 & 0 & $2.1 \times 10^{9}$ \\
\hline Ketones $\mathrm{C}>3$ & $1.0 \times 10^{8}$ & $2.0 \times 10^{9}$ & $1.7 \times 10^{10}$ \\
\hline Methylglyoxal & 0 & 0 & $6.8 \times 10^{9}$ \\
\hline Methanol & 0 & 0 & $3.7 \times 10^{9}$ \\
\hline Methylhydroperoxide & 0 & 0 & $7.9 \times 10^{8}$ \\
\hline Peroxymethacryloyl nitrate & 0 & 0 & $1.0 \times 10^{9}$ \\
\hline Methylvinylketone & 0 & 0 & $1.3 \times 10^{9}$ \\
\hline Benzyl nirate & 0 & 0 & $3.0 \times 10^{3}$ \\
\hline PeroxyacetyInitrate & $7.5 \times 10^{9}$ & 0 & $2.2 \times 10^{10}$ \\
\hline Phenol & 0 & 0 & $1.8 \times 10^{5}$ \\
\hline PeroxypropionyInitrate & $5.0 \times 10^{8}$ & 0 & $4.0 \times 10^{9}$ \\
\hline Alkenes $C>4$ & 0 & $2.3 \times 10^{10}$ & $3.4 \times 10^{9}$ \\
\hline Aldehydes C > 2 & $2.0 \times 10^{7}$ & $3.1 \times 10^{8}$ & $4.3 \times 10^{9}$ \\
\hline Higher order organic acid & 0 & 0 & $8.1 \times 10^{7}$ \\
\hline Alcohols $C>2$ & 0 & 0 & $1.5 \times 10^{8}$ \\
\hline Toluene & $2.0 \times 10^{6}$ & $2.0 \times 10^{10}$ & $2.2 \times 10^{10}$ \\
\hline m-xylene & 0 & $1.3 \times 10^{10}$ & $4.8 \times 10^{9}$ \\
\hline
\end{tabular}

\section{ACPD}

7, 8361-8393, 2007

\section{Development of a SOA formation mechanism}

L. E. Olcese et al.

\section{Title Page}

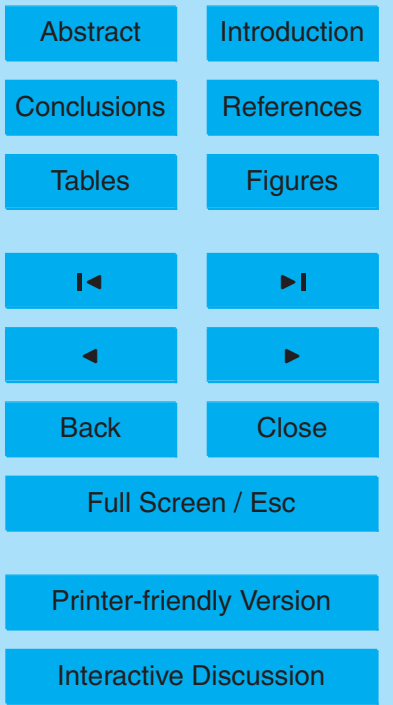


Table 5. Final concentrations of the most important compounds that produce SOA in the ambient simulations.

\begin{tabular}{lllll}
\hline Compound & $\begin{array}{l}\text { Aerosol phase } \\
\text { Urban- } \\
\text { influenced } \\
\text { site } \\
{\left[\mu \mathrm{g} \mathrm{m}^{-3}\right]}\end{array}$ & $\begin{array}{l}\text { Aerosol phase } \\
\text { Rural site } \\
{\left[\mu \mathrm{g} \mathrm{m}^{-3}\right]}\end{array}$ & $\begin{array}{l}\text { Gas phase } \\
\text { Urban-influenced } \\
\text { site } \\
{\left[\mu \mathrm{g} \mathrm{m}^{-3}\right]}\end{array}$ & $\begin{array}{l}\text { Gas phase } \\
\text { Rural site } \\
{\left[\mu \mathrm{g} \mathrm{m}^{-3}\right]}\end{array}$ \\
\hline A-DI & $1.18 \times 10^{-1}$ & $9.40 \times 10^{-4}$ & $2.48 \times 10^{-1}$ & $1.29 \times 10^{-3}$ \\
ACHO & $1.15 \times 10^{-1}$ & $4.83 \times 10^{-4}$ & $2.17 \times 10^{-5}$ & $2.51 \times 10^{-7}$ \\
IALD & $3.20 \times 10^{0}$ & $7.92 \times 10^{0}$ & $1.20 \times 10^{-8}$ & $4.98 \times 10^{-6}$ \\
INPN & $1.27 \times 10^{0}$ & $2.12 \times 10^{0}$ & $7.68 \times 10^{-8}$ & $5.67 \times 10^{-7}$ \\
ISNP & $1.12 \times 10^{0}$ & $2.09 \times 10^{-2}$ & $1.14 \times 10^{-18}$ & $2.96 \times 10^{-20}$ \\
NITP & $4.38 \times 10^{-1}$ & $4.79 \times 10^{-3}$ & $6.95 \times 10^{-7}$ & $2.03 \times 10^{-6}$ \\
PINT & $9.46 \times 10^{-1}$ & $1.51 \times 10^{-1}$ & $5.28 \times 10^{-15}$ & $4.58 \times 10^{-14}$ \\
$\alpha-$ pinene & & & $9.45 \times 10^{6}$ & $1.46 \times 10^{9}$ \\
Isoprene & & & $2.23 \times 10^{10}$ & $4.70 \times 10^{11}$ \\
Limonene & & & $4.81 \times 10^{6}$ & $6.13 \times 10^{8}$ \\
Toluene & & & $2.23 \times 10^{10}$ & $3.75 \times 10^{9}$ \\
Xylene & & & $4.79 \times 10^{9}$ & $3.28 \times 10^{9}$ \\
Total SOA & 7.2 & 10.2 & & \\
\hline
\end{tabular}

7, 8361-8393, 2007

Development of a SOA formation mechanism

L. E. Olcese et al.

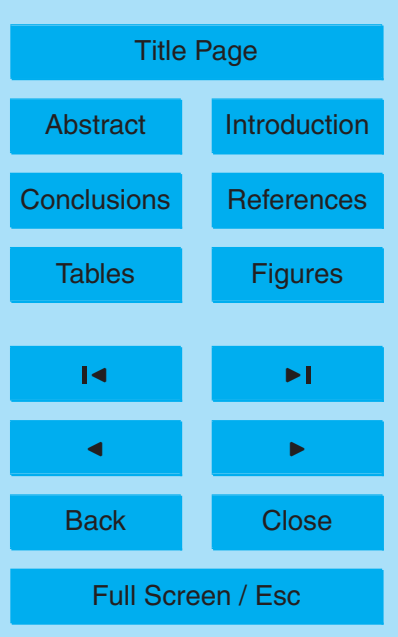

Printer-friendly Version

Interactive Discussion 


\section{ACPD}

7, 8361-8393, 2007

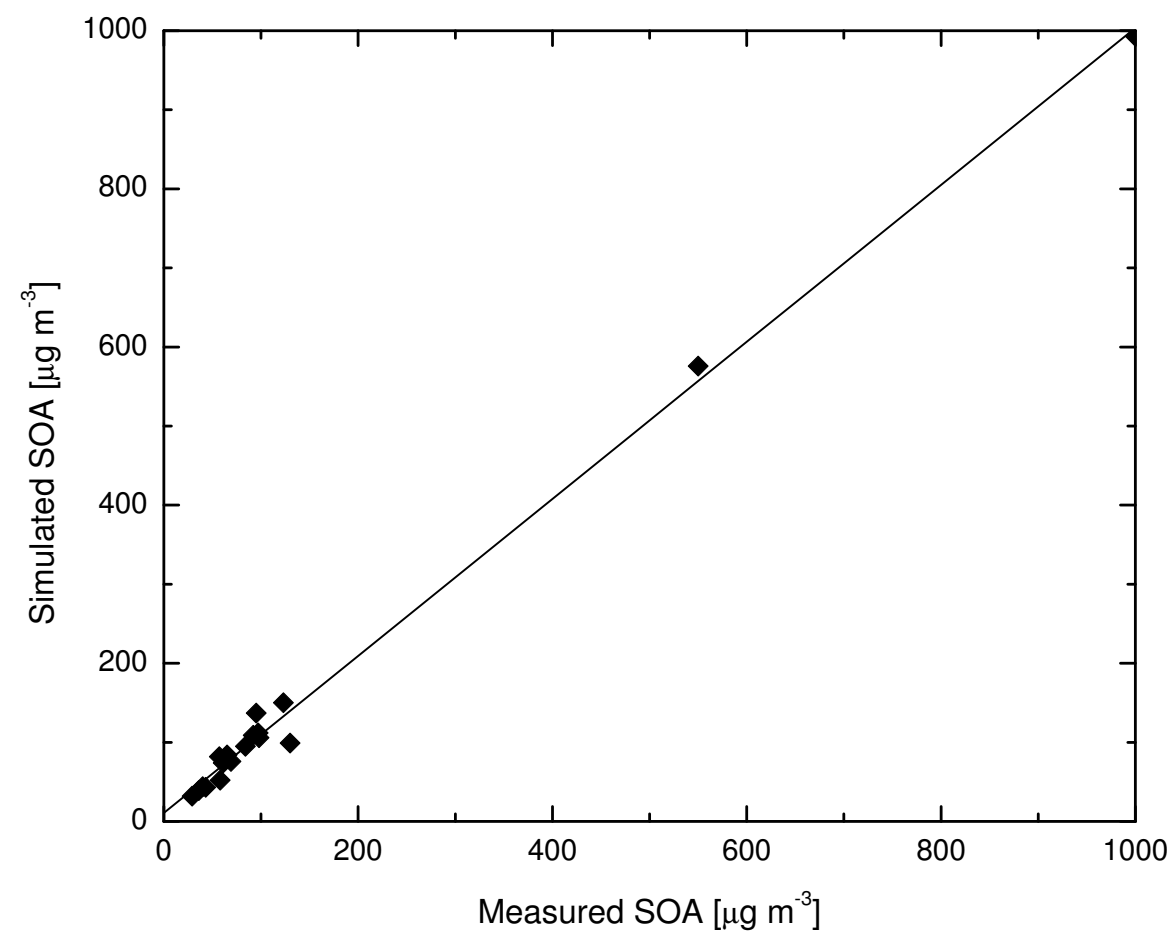

\section{Development of a SOA formation mechanism \\ L. E. Olcese et al.}

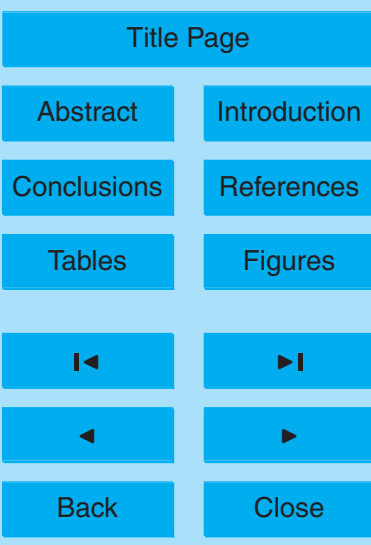

Full Screen / Esc

Fig. 1. Plot of simulated vs. measured SOA concentrations for several smog chamber experiments.

Printer-friendly Version

Interactive Discussion 


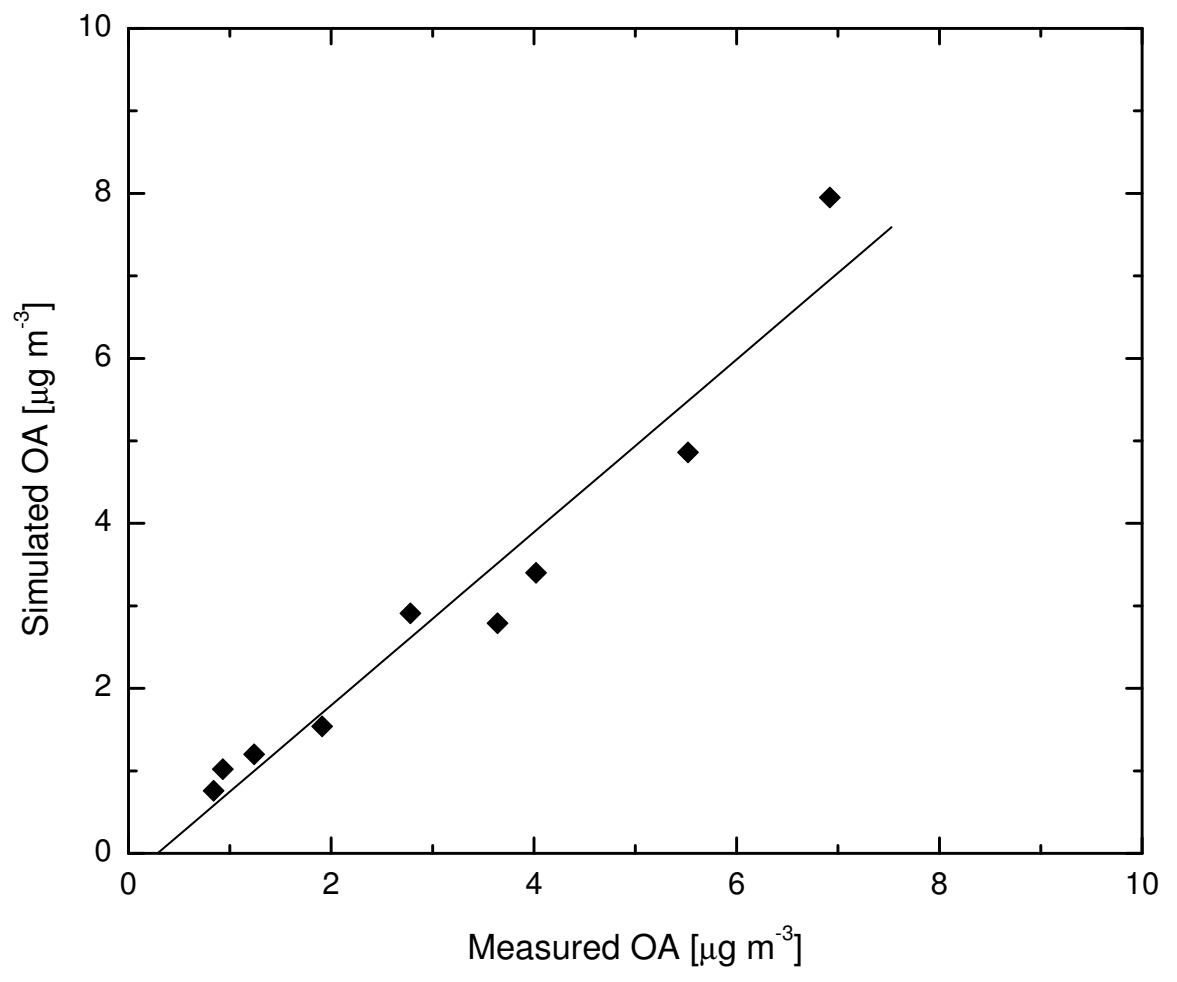

Fig. 2. Plot of simulated vs. measured OA concentrations for the TORCH 2003 campaign.

\section{ACPD}

7, 8361-8393, 2007

\section{Development of a SOA formation mechanism \\ L. E. Olcese et al.}

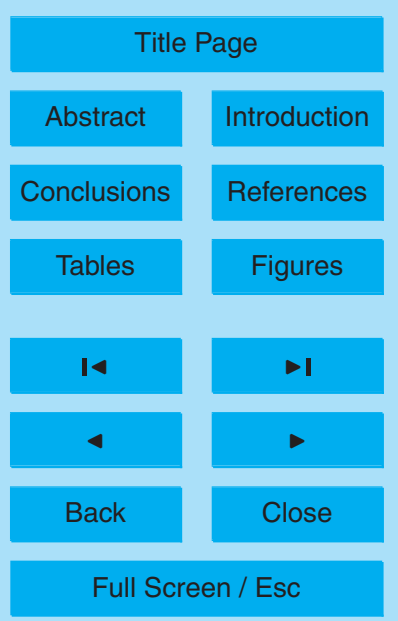

Printer-friendly Version

Interactive Discussion 


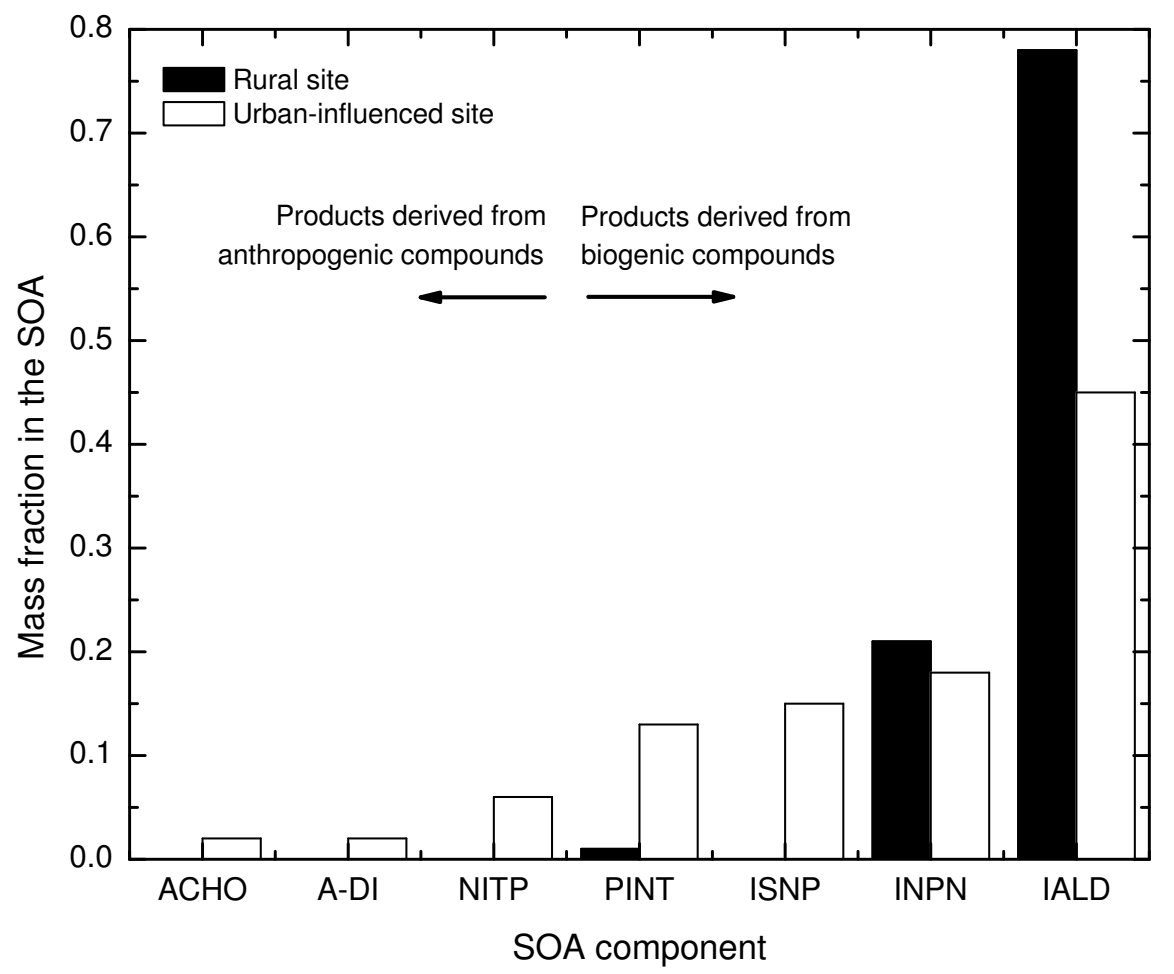

Fig. 3. Species that partition to the SOA phase under two different initial conditions.

\section{ACPD}

7, 8361-8393, 2007

\section{Development of a SOA formation mechanism}

L. E. Olcese et al.

\section{Title Page}

\section{Abstract} Introduction

Conclusions

References

Tables

Figures

14

4

Back

Close

\section{Full Screen / Esc}

Printer-friendly Version

Interactive Discussion 


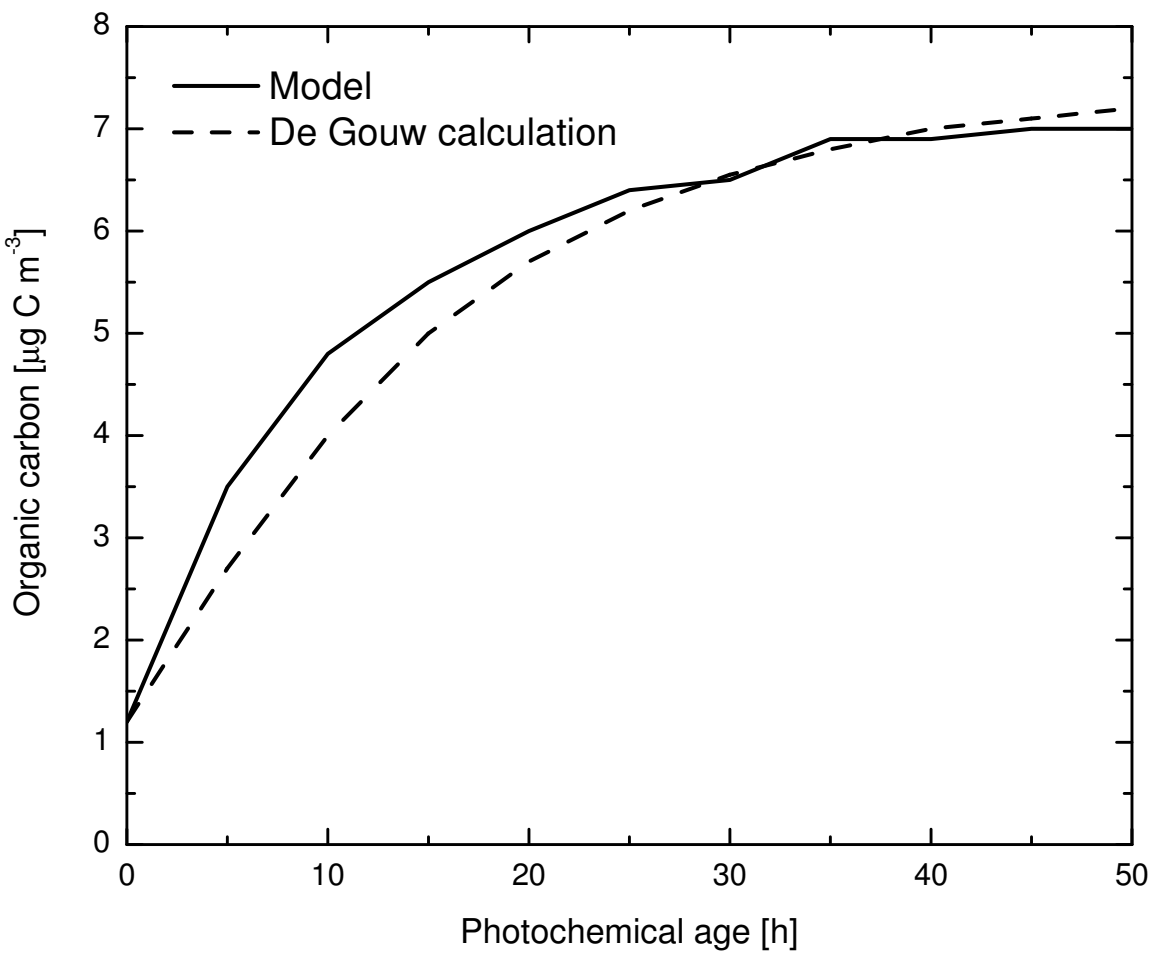

7, 8361-8393, 2007

\section{Development of a} SOA formation mechanism

L. E. Olcese et al.

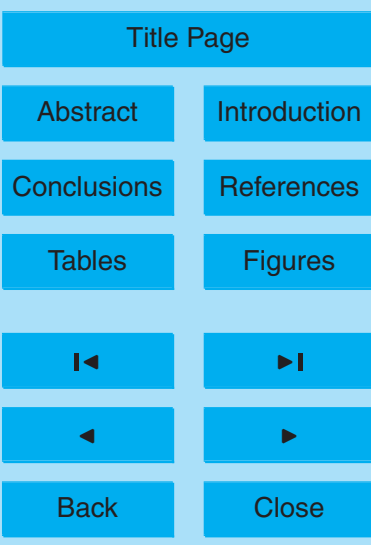

Full Screen / Esc

Fig. 4. Evolution of the organic carbon in the SOA phase concentration under the conditions reported by de Gouw et al. (2005).

Printer-friendly Version

Interactive Discussion 